\title{
Working
}

Paper 


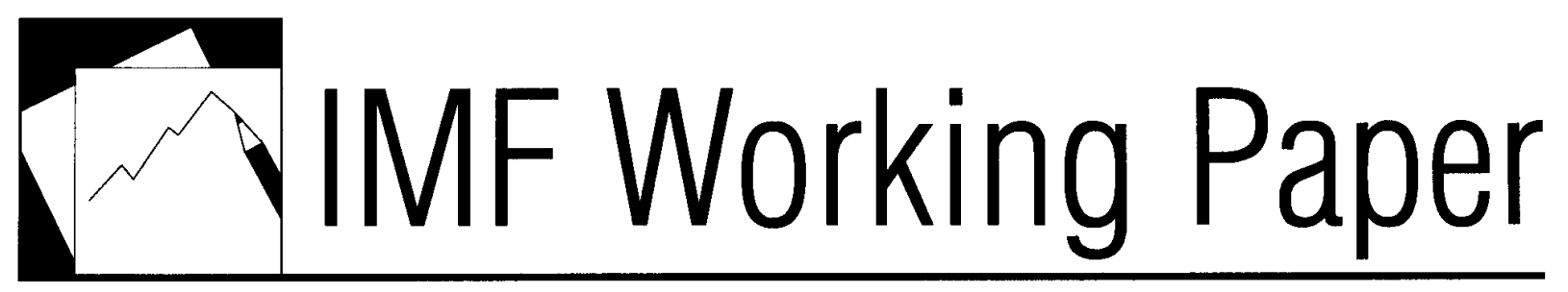

Heterogeneous Bank Lending Responses to Monetary Policy: New Evidence from a Real-time Identification

John C. Bluedorn, Christopher Bowdler, and Christoffer Koch 


\title{
IMF Working Paper
}

\author{
Research Department
}

\section{Heterogeneous Bank Lending Responses to Monetary Policy: New Evidence from a Real-time Identification ${ }^{1}$}

\author{
John C. Bluedorn \\ Research Department \\ International Monetary Fund
}

\author{
Christopher Bowdler \\ Department of Economics \\ University of Oxford
}

\author{
Christoffer Koch \\ Research Department \\ Federal Reserve Bank of \\ Dallas
}

Authorized for distribution by Thomas Helbling

May 2013

This Working Paper should not be reported as representing the views of the IMF.

The views expressed in this Working Paper are those of the author(s) and do not necessarily represent those of the IMF or IMF policy. Working Papers describe research in progress by the author(s) and are published to elicit comments and to further debate.

\begin{abstract}
We present new evidence on how heterogeneity in banks interacts with monetary policy changes to impact bank lending. Using an exogenous policy measure identified from narratives on FOMC intentions and real-time economic forecasts, we find much greater heterogeneity in U.S. bank lending responses than that found in previous research based on realized federal funds rate changes. Our findings suggest that studies using realized monetary policy changes confound the monetary policy's effects with those of changes in expected macrofundamentals. We also extend Romer and Romer (2004)'s identification scheme, and expand the time and balance sheet coverage of the U.S. banking sample.
\end{abstract}

JEL Classification Numbers: E44; E50; G21

Keywords: Monetary Transmission; Lending Channel; Monetary Policy Identification; Banking

Author’s E-Mail Address: jbluedorn@imf.org; christopher.bowdler@economics.ox.ac.uk; Christoffer.Koch@dal.frb.org

\footnotetext{
${ }^{1}$ We thank Adam Ashcraft for sharing his bank-level balance sheet dataset. We would also like to thank Mustafa Caglayan, John Duca, Richard Mash, John Muellbauer, Anthony Murphy, David Romer, and seminar participants at the University of Southampton, Magyar Nemzeti Bank (Hungarian Central Bank), the Department of Economics and the Saïd Business School, Oxford, Lehman Brothers, London, and the Federal Reserve Bank of Dallas for comments on earlier versions of this paper. The views expressed herein are those of the authors and should not be attributed to the IMF, its Executive Board, or its management, nor the Federal Reserve Bank of Dallas or the Federal Reserve System. Any errors or omissions are the sole responsibility of the authors.
} 


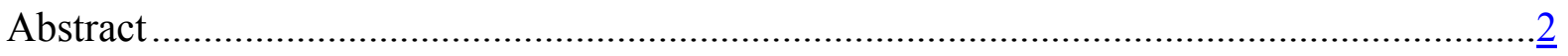

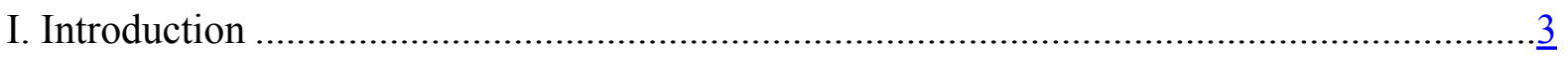

II. Bank Lending and Monetary Policy................................................................. $\underline{5}$

A. Lending Responses to Endogenous Monetary Policy Changes ............................ $\underline{5}$

B. Policy Endogeneity and Bank Characteristics ................................................. $\underline{8}$

III. Econometric Methodology................................................................................ 10

A. Monetary Policy Identification .................................................................. $\frac{10}{15}$

B. Regression Specification ........................................................................ $\frac{15}{18}$

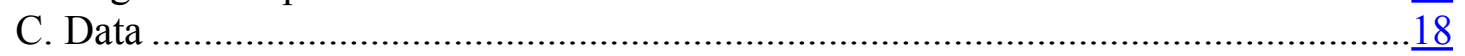

IV. Empirical Results ........................................................................................... 24

A. Effects of Bank Size and Holding Company Status ......................................... $\frac{25}{28}$

B. Effects of Balance Sheet Composition............................................................ $\frac{28}{28}$

C. Stability of the Baseline Results................................................................... 29

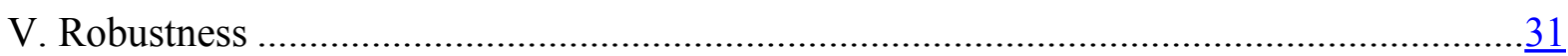

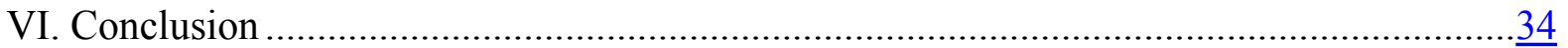

\section{TABLES}

1. Policy Identification Regression .................................................................... 12

2. Bank Level Summary Statistics ..............................................................................23

3. Comparison of Dynamic Lending Response of a Representative Bank ...........................24

4. Heterogeneity in Lending Responses due to Bank Characteristics ...................................

5. Bank Holding Company Lending Responses .....................................................

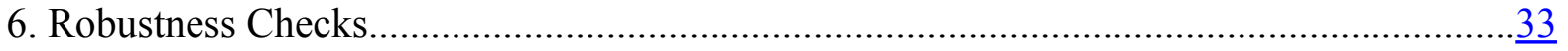

\section{FigURES}

1. Endogenous and Exogenous Monetary Policy Shocks ............................................... 15

2. Macroeconomic Controls During the Sample............................................................... 19

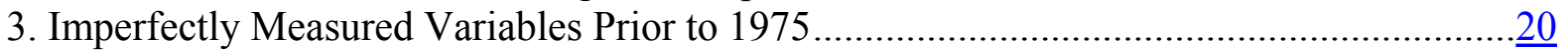

4. Assumptions Regarding Timing ........................................................................

5. Assumptions Regarding Interpolation ...............................................................

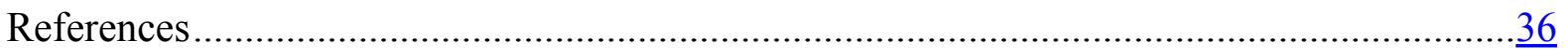




\section{INTRODUCTION}

The role of the banking sector in the transmission of monetary policy has been studied in great detail in both the theoretical and empirical literature (for a review of the various channels of monetary transmission, see Bernanke and Gertler, 1995). Following the pioneering work of Kashyap and Stein (2000), a number of empirical studies have explored the heterogeneity in bank lending responses to monetary policy. If a bank's characteristics are related to its ability to access non-deposit financing sources, then the existence of a lending channel implies that lending responses to monetary policy are related to bank characteristics. Kashyap and Stein show that banks with relatively large and liquid asset bases are better able to shield their lending growth during periods of tight monetary policy. The same phenomenon has been documented for banks with relatively high equity capital-to-assets ratios (Kishan and Opiela, 2000), banks whose loan books are readily securitized (Loutskina, 2011), banks affiliated to a holding company (Ashcraft, 2006), and banks that can raise funds from international operations (Cetorelli and Goldberg, 2012).

A fundamental question confronted by each of these papers is whether or not any differences in lending responses linked to a specific bank characteristic are the result of differences in loan supply (as in the lending and broad credit channels), or are a mixture of differences in loan supply and loan demand. There is now an extensive literature that argues that loan demand conditional upon one or more bank characteristics is homogenous. ${ }^{2}$ With homogenous loan demands, any heterogeneity in lending responses given bank characteristics is consistent with the existence of a bank lending channel working through loan supply.

By contrast, much less attention has been devoted to the question of what measure of monetary policy is appropriate for the assessment of bank lending behavior. Most papers use the change in the effective (realized) federal funds rate to capture monetary policy, reflecting the fact that the Federal Open Market Committee (FOMC) has targeted the federal funds rate for much of the last 30 years. ${ }^{3}$ While federal funds rate changes initiated by the FOMC are surely exogenous to the circumstances facing any single bank, the factors to which policymakers respond (e.g., expected output growth and inflation) are also potential determinants of individual bank lending, operating through both loan demand and loan supply changes. This raises the possibility that lending responses to federal funds rate changes confound the effects of monetary policy and other lending market drivers. Furthermore, if the strength of any effects from confounding variables is related to bank characteristics, the heterogeneity in lending responses to monetary policy will not be correctly estimated.

\footnotetext{
${ }^{2}$ See Ashcraft (2006) for a discussion of this evidence.

${ }^{3}$ See Meulendyke (1998) for an in-depth description of the Federal Reserve's choices of policy instrument over time. Alternative monetary policy measures which have been used in the literature on bank lending include those due to Boschen and Mills (1991, 1995), Strongin (1995), and Bernanke and Mihov (1998). See section 2 for further discussion.
} 
Motivated by these possibilities, we evaluate the heterogeneity in bank lending responses to target federal funds rate changes that are plausibly exogenous to expected output growth, inflation, unemployment, and capacity utilization. The identification of this monetary policy component elaborates upon and extends earlier work by Romer and Romer (2004). They combined narrative evidence on Federal Reserve target rate intentions with in-house macroeconomic forecasts (the Greenbook) in order to control for endogenous policy changes (policy changes in response to the economy). Bank lending responses to the identified policy measure are compared with lending responses estimated from realized federal funds rate changes that have been the focus of most previous research.

Our results highlight four important differences between bank lending responses to exogenous and endogenous components of monetary policy. First, one year after an exogenous monetary contraction, the reduction in lending growth at the average bank which is not part of a holding company is up to twice that from a rise in the realized federal funds rate. Second, the amount by which a bank can shield its lending growth from a monetary policy contraction, either through accessing a large asset base or drawing on funds from affiliates in a holding company, is up to four times larger when estimated purely in response to identified, exogenous monetary policy. Third, the share of bank assets held as securities mitigates the lending response to a realized federal funds rate increase, but amplifies the lending contraction to an exogenous federal funds rate increase. Moreover, the ratio of cash-to-assets shields lending growth from an exogenous monetary tightening, but is only weakly correlated with lending responses to realized federal funds rate increases.

We offer explanations for these findings in terms of the endogeneity of monetary policy. They provide a new perspective on the measurement of balance sheet liquidity and the consequences of shifts in balance sheet composition for the strength of monetary policy propagation. Our fourth and last finding qualifies the results on balance sheet composition. Following the Federal Reserve's introduction of the source of strength doctrine for bank holding companies in 1987, the effects of asset composition on lending responses to monetary policy occur only among banks that are not part of a holding company. Affiliated banks appear to be able to smooth lending in the face of monetary policy shocks using the internal capital markets of the holding company, such that balance sheet composition is unrelated to lending responses to monetary policy.

To place our paper in context, it is important to consider how potential biases from confounding monetary policy with other loan demand and loan supply determinants have been handled in previous research. Each of the papers mentioned earlier directly controls for output growth, inflation, or both, in their empirical models of bank lending growth. To the extent that such variables account for the underlying drivers of endogenous monetary policy changes that also affect loan demand and supply, their inclusion in a lending growth regression enables the effects of exogenous monetary policy to be identified. Under the assumption that loan demand is homogenous across banks with similar characteristics, monetary policy's effect on lending 
through loan supply can be isolated through interactions of monetary policy changes with the relevant bank characteristics.

The starting point for our paper is that current output growth and inflation are not the only sources of endogenous policy - a forward-looking policymaker who desires to minimize cyclical fluctuations will also respond to their perceived prospects for the economy. If the policymaker's economic forecasts correlate with private sector expectations for growth and inflation, then the monetary policy stance can move with loan demand and supply in a manner that is systematically related to observable bank characteristics. For instance a well capitalized bank might hold a more cyclically sensitive loan portfolio, so any heterogeneity in lending responses to changes in the federal funds rate might be driven naturally by different sensitivity to economic fundamentals that policy makers respond to in real time, rather than related to balance sheet frictions proxied by bank capitalization. Our results highlight instances in which this appears to be the case. In light of these findings, we argue that future studies of bank lending behavior should take into account the forward-looking component of endogenous monetary policy.

The remainder of the paper is structured as follows. In section 2, we explain how endogenous monetary policy movements may induce biased estimates of lending responses to monetary policy. Motivated by these possibilities, in section 3 we outline an identification strategy for exogenous monetary policy. We then discuss the bank-level econometric framework and data that we use to compare lending responses to identified policy changes with lending responses to realized changes in the federal funds rate. In section 4, we present our core results. We continue in section 5 with a consideration of their robustness to changes in estimation and data definitions. Finally, we conclude in section 6 with a summary and a discussion of the importance of monetary policy identification for future research concerning bank lending behavior.

\section{Bank Lending And Monetary Policy}

\section{A. Lending Responses to Endogenous Monetary Policy Changes}

How might endogenous monetary policy contaminate estimates of the lending channel? Here, we outline the potential biases affecting the estimates in the literature that rely upon the effective federal funds rate to measure monetary policy. In each of the cases discussed, the key idea is that expectations over output growth and inflation affect both policy and bank lending choices. Standard lending growth regressions fail to account for this, leading to an omitted variable problem. This biases the estimated response of bank lending to monetary policy changes, even when lending responses are conditional upon bank characteristics, a focus of much recent research. To assess the relevance of these potential biases, we compare bank lending 
responses to our identified, exogenous monetary policy changes (described in section 3) and to the realized federal funds rate changes that have been used in previous research. ${ }^{4}$

Studies of bank lending responses to monetary policy typically estimate regressions of the form:

$$
\Delta L_{i, t}=\alpha+M_{t}^{\prime} \beta+B_{i, t}^{\prime} \gamma+B_{i, t}^{\prime} M_{t} \delta+Z_{i, t}^{\prime} \phi+\varepsilon_{i, t}
$$

where $i$ indexes banks, $t$ indexes time, $\Delta L$ denotes the percentage growth of total loans measured at current prices, $M$ is a monetary policy measure, $B$ is a vector of $J$ bank-specific characteristics, $Z$ is a vector of $K$ control variables, and $\varepsilon$ is a mean-zero error term. All other Greek letters denote parameters. In practice, bank lending regressions are much richer than equation (1), typically including autoregressive terms and dynamics in $M$ and $B$. In section 3, we describe a more complex version of model (1) that incorporates these features. It also will provide the basis for our empirical work. However, the present specification is sufficient to illustrate our argument. $^{5}$

As noted in the introduction, the vector $B$ comprises bank characteristics that proxy access to non-reservable finance (viz., liabilities that do not require reserves or assets on hand). These might include total bank assets, bank holding company affiliation, an indicator for whether a bank operates internationally, and measures of balance sheet composition, such as equity capital-to-assets, securities-to-assets, or cash-to-assets ratios. In the aftermath of contractionary monetary policy, banks that can access funds via these sources may shield lending growth from the effects of an erosion of reserves and deposits.

What interpretation can be given to the cross effects (interactions) between monetary policy and bank characteristics? If the bank characteristics proxy access to funds that matter for

\footnotetext{
${ }^{4}$ An alternative to identifying exogenous monetary policy changes would be to directly include the omitted expectations over output growth and inflation in the lending regressions. The key difficulty with this approach is mapping the expectations measure (which is a snapshot of views on future prospects at a particular moment in time) to the quarterly frequency. If expectations are measured late in the quarter, then we would be implicitly using some future information to explain lending earlier in the quarter. If expectations are taken from sometime in the prior quarter, then we would be using stale information, failing to eliminate much of the endogeneity problem. To avoid these problems, we opt to use policymakers' expectations about the economy to form identified, exogenous monetary policy changes, since we can match measures of the policymakers' expectations to specific policy decisions (viz., FOMC meetings). These can then be mapped to the quarterly frequency. See section 3.A for a detailed description.
}

${ }^{5}$ Alternatives to the single-step regression model have also been considered in the literature. For example, Kashyap and Stein (2000) adopt a two-stage procedure, where the cross-sectional sensitivity of lending growth to balance sheet liquidity is estimated in a first stage, and a time series regression relating these cross-sectionally estimated liquidity constraints to monetary policy is estimated in a second stage. We do not adopt the two-stage approach in this paper. 
loan supply, then the cross effects $(\delta)$ represent how much the bank characteristics help to shield loan supply from monetary policy changes (or amplify its effects). However, many bank characteristics are also correlated with drivers of a bank's load demand. For example, large banks (proxied by equity capital or total assets) may cherry pick customers whose loan demand is relatively stable, while poorly capitalized banks may be overlooked by safe borrowers and forced to do business with risky customers whose loan demand is relatively volatile and sensitive to the business cycle. In other words, loan supply and demand effects of monetary policy changes conditional on bank characteristics may be confounded.

On the other hand, Ashcraft (2006) presents evidence that bank holding company affiliation is less closely linked to the customer mix and hence loan demand, and thus is preferable as an indicator for loan supply conditions. In this paper, we do not add to this debate. Instead, we consider the wide range of characteristics that have been studied in the literature. However, throughout our discussion we are mindful of the interpretations that can be given to cross effects between monetary policy and individual bank characteristics.

The monetary policy measure $M$ most often employed is the change in the period average effective federal funds rate, which has been the Federal Reserve's operating target since at least 1994, and arguably over much of the post-war period. ${ }^{6}$ Increases in the federal funds rate target induce leftward shifts of banks' loan supply schedules via the narrow and broad lending channels described in the introduction. These raise lending rates and reduce lending volumes. However, when the federal funds rate target is increased in response to forecasts of higher future economic growth and/or inflation, estimation of this relationship is no longer straightforward. In such circumstances, any loan supply contraction due to tight monetary policy may coincide with a rightward shift of loan demand, as consumers borrow against expected future income and firms invest in response to an improving outlook for profits. The loan demand shift will attenuate the reduction in lending from a monetary tightening and the $\beta$ estimated from equation (1) will not capture the full effect of monetary policy. A similar result may arise via the effects of expected inflation. In particular, reductions in bank lending from a rise in the federal funds rate may be muted because the demand for loans in nominal units rises with expected inflation. As in the example based on expected economic growth, equilibrium lending is subject to countervailing

\footnotetext{
${ }^{6}$ See Meulendyke (1998) for historical evidence on the Federal Reserve's policy tool choices. Alternative policy measures due to Boschen and Mills $(1991,1995)$ and Bernanke and Mihov (1998) have also been employed in the literature (Kashyap and Stein, 2000). These measures of policy explicitly address possible changes to the instrument of policy through time, but still capture the endogenous stance of policy. As such, we believe that the arguments developed in this section are applicable to them. Loutskina (2005) and Cetorelli and Goldberg (2012) consider Strongin's (1995) identification of exogenous movements in non-borrowed reserves. While this approach controls for reserve demand shocks, it does not control for endogenous policy moves by a forward-looking central bank. Jonas and King (2008) briefly consider the original Romer and Romer (2004) policy measure, which does control for policy endogeneity. However, this is used only as a robustness test in a study that focuses on the impact of bank efficiency on lending responses to general federal funds rate movements. Jonas and King do not consider the consequences of policy endogeneity for lending responses.
} 
effects from loan demand and loan supply, such that the $\beta$ estimated from equation (2) is attenuated.

The drivers of endogenous monetary policy may also influence equilibrium lending via bank loan supply. The availability of non-reservable finance to banks is likely to vary positively with expected economic growth. At the start of cyclical upturns, institutional investors (e.g., pension funds, sovereign wealth funds) may invest more heavily in equities and loan-backed securities than in more traditional fixed income assets, as their risk appetite grows and they search for yield. To the extent that banks use equity issues and the securitization of loans to generate funding for new lending, loan supply would rise at each level of market interest rates.

Similarly, in models featuring information asymmetries and monitoring costs, loan supply incorporates an external finance premium that varies positively with lender risk aversion and negatively with borrower net worth (Bernanke and Gertler, 1989). Expansion phases of the business cycle are typically associated with increases in lenders' risk appetite and agents' net worth, such that the external finance premium falls and loan supply expands. We do not emphasize any one of these channels ahead of the others. Instead, we highlight that when loan supply is affected by any one of them, the response of lending growth to the federal funds rate will be attenuated - the leftward shift of loan supply from tight policy is offset by a rightward shift of loan supply via one of the channels described. Furthermore, this will be the case even when controlling for current economic growth and inflation. The effect derives from the fact that expected economic conditions may influence monetary policy and loan supply simultaneously.

\section{B. Policy Endogeneity and Bank Characteristics}

An important question is whether or not pro-cyclical loan demand and loan supply affect the cross effects $\delta$ in equation (1) that measure heterogeneity in bank lending responses. As discussed in the introduction, these are the terms that proxy the bank-level financial constraints that underpin the aggregate lending channel of monetary policy. Even if banks are homogeneous and equally affected by expected macroeconomic conditions, the presence of endogenous variation in monetary policy would still attenuate the $\delta$ coefficients, via the mechanisms described above.

Alternatively, suppose that the attenuation of lending responses to monetary policy varies systematically with bank characteristics. Then, estimates of equation (1) which use the realized federal funds rate may either obscure or induce systematic heterogeneity in bank responses to monetary policy. In this sub-section, we describe two examples of potential biases: (i) changes in expected macroeconomic conditions induce loan supply shifts that depend on bank characteristics; and (ii) changes in expected macroeconomic conditions induce bank-specific loan demand shifts that are associated with bank characteristics. 
Banks that face financing constraints, either due to a lack of affiliates, assets, equity capital, or liquidity, may draw more heavily on the additional funds available during cyclical upturns, because of the fact that their lending was previously constrained. If this is the case, the rightward shifts of their loan supply curves from improved macroeconomic expectations, which offset the leftward shifts from monetary tightening, would be larger, such that the net reduction in lending during periods of partially endogenous monetary tightening will be attenuated. This example is significant. It suggests that the evidence for financing constraints amongst banks will be understated when a measure of the endogenous stance of monetary policy such as the realized federal funds rate is used.

Turning to the second possibility listed above, Kashyap and Stein (2000) advocate a rational buffer stocking theory to explain a possible correlation between loan demand curve shifts and bank characteristics. Under the assumption that some banks concentrate their lending in regions or industries that are especially sensitive to aggregate demand conditions, it is rational for such banks to select characteristics that help accommodate volatile loan demand (e.g., bank holding company affiliation or high balance sheet liquidity). When the federal funds rate rises during a cyclical expansion, shifts in individual loan demand curves will be largest amongst banks exhibiting the characteristic in question. The attenuation of lending growth reversals following rises in the federal funds rate would then be largest amongst that category of banks. As in the first case discussed, this effect would manifest as positive bias to the estimate of $\delta$. Evidence that banks with access to liquidity can shield lending growth from Federal Reserve policy would be overstated. ${ }^{7}$

We close this section by noting that these thought experiments raise the possibility that even a purely exogenous monetary policy measure will elicit estimates of $\delta$ that measure something other than banks' ability to shield loan supply by virtue of their characteristics. For example, banks that can access liquidity may face different loan demand elasticities and therefore adjust their lending differently for that reason. Some characteristics may be more prone to such effects than others. As mentioned earlier, Ashcraft (2006) contends that the properties of loan demand are similar across banks, conditional upon bank holding company status (affiliation/non-affiliation). In this case, a comparison of lending responses by bank holding company status is more likely to reflect genuine differences in banks' access to alternative finance. We return to this issue when discussing our empirical results in section 4 . The point that we emphasize at this stage is that such effects impact all measures of monetary policy, both endogenous and exogenous. The main advantage of considering exogenous policy measures is that their effects on bank lending are less likely to be affected by the sources of bias discussed in this section.

\footnotetext{
${ }^{7}$ There is a caveat. Banks trading with cyclically sensitive customers may also face relatively more interest rate elastic loan demand curves, such that drops in loan demand from a rise in the federal funds rate will be larger. This potentially offsets the lending increase arising from a relatively large rightward shift of the loan demand curve due to stronger macroeconomic expectations.
} 


\section{ECONOMETRIC Methodology}

In this section, we outline the methods that we use in comparing bank lending responses to exogenous monetary policy changes with realized federal funds rate changes. We first describe the identification procedure used to isolate exogenous variation in the monetary policy rate. Then, we outline the regression models that underlie our core results. Finally, we describe the data we use in the estimation.

\section{A. Monetary Policy Identification}

To identify exogenous variation in the U.S. monetary policy, we follow and extend the two-step procedure outlined by Romer and Romer (2004), who consider U.S. monetary policy over the period 1969-96. In the first step, narrative evidence is used to determine the size of the federal funds rate change targeted by the Federal Open Market Committee (FOMC) at their scheduled meetings. The advantage of this measure of monetary policy intentions is that during episodes of reserve targeting (e.g., under Volcker's chairmanship of the FOMC), it does not respond to supply and demand shocks in the reserve market that are unrelated to monetary policy. In contrast, the effective federal funds rate (the market clearing rate in the reserve market) will respond to such factors.

We extend the original Romer and Romer (2004) target series by appending the FOMC's announced federal funds target rate changes for 1997 to 2006, the last year for which Greenbook forecasts are currently publicly available. Such announcements began in February 1994, overlapping with the original Romer and Romer series for 2 years. Although the announced target series does not capture all of the narrative evidence incorporated in the Romer and Romer (2004) series, we argue that the pooling of the two is defensible, since the transparency of policy intentions and the public announcement of policy changes are strongly related. During the overlapping period of 1994-96, the two series have a correlation that is essentially $1 .^{8}$ The extension of the target rate series in this way ensures that we are able to recover exogenous variation in U.S. monetary policy for a longer sample period than that covered by Romer and Romer (2004). ${ }^{9}$

In the second step, the targeted federal funds rate change is regressed upon the Federal Reserve's Greenbook (in-house) forecasts for real output growth, inflation, and unemployment over horizons of up to two quarters. These represent the central objective variables of the Federal

\footnotetext{
${ }^{8}$ There is one instance in which the series differ. For the meeting on September 28, 1994, Romer and Romer (2004) argue that the language associated with the FOMC transcripts amounted to the intention to tighten by 12.5 basis points, even though there was no change in the announced, target federal funds rate.

${ }^{9}$ Romer and Romer (2004) conduct some sub-sample analysis on their estimates, finding that the implied reaction function pre versus post Volcker is not markedly different. Their findings and the results in Orphanides (2003) suggest that pooling over time is appropriate (or at least approximately so).
} 
Reserve. ${ }^{10}$ Additionally, we supplement the specification with real-time Greenbook information on manufacturing capacity utilization. The empirical relevance of capacity utilization is emphasized by Giordani (2004), who shows that controlling for such a proxy for actual output relative to potential is crucial for accurate policy identification. In the present application, we treat forecasts of manufacturing capacity utilization as proxies for latent policymaker perceptions concerning the cyclical position of the economy, which may contribute to policy decisions even after controlling for real output growth, inflation, and unemployment. Formally, we estimate the following regression:

$$
\begin{aligned}
\Delta f f_{m}= & \alpha+\beta f f_{m-1} \\
& +\sum_{l=-1}^{2} \varphi_{l}^{y} \widehat{\Delta y_{m, l}}+\sum_{l=-1}^{2} \varphi_{l}^{\Delta y}\left(\widehat{\Delta y_{m, l}}-\widehat{\Delta y_{m-1, l}}\right)+\sum_{l=-1}^{2} \varphi_{l}^{\pi} \widehat{\pi_{m, l}}+\sum_{l=-1}^{2} \varphi_{l}^{\Delta \pi}\left(\widehat{\pi_{m, l}}-\widehat{\pi_{m-1, l}}\right) \\
& +\sum_{l=-1}^{2} \varphi_{l}^{n} \widehat{n_{m, l}}+\sum_{l=-1}^{2} \varphi_{l}^{\Delta n}\left(\widehat{n_{m, l}}-\widehat{n_{m-1, l}}\right)+\sum_{l=-1}^{2} \varphi_{l}^{u} \widehat{u_{m, l}^{m f g}}+\sum_{l=-1}^{2} \varphi_{l}^{\Delta u}\left(\widehat{u_{m, l}^{m f g}}-\widehat{u_{m-1, l}^{m f g}}\right)+\varepsilon_{m}
\end{aligned}
$$

where $m$ indexes FOMC meetings, $\ell$ indexes the forecast quarter relative to the current meeting's quarter, $f f$ is the target federal funds rate level, $\Delta y$ is real output growth, $\pi$ is inflation, $n$ is the unemployment rate, $u^{m f g}$ is the manufacturing capacity utilization index measured in percentage points, and $\varepsilon$ is a mean-zero error term. A hat denotes the real-time forecast for a variable. All other lowercase Greek letters denote population parameters. Notice that the specification employs a larger set of unemployment forecasts than Romer and Romer (2004) and additionally includes real-time back-, now- and forecasts of manufacturing capacity utilization.

The results obtained from estimating equation (2) for a sample of 346 FOMC meetings from the period 1969-2006 are reported in Table 1. The sums of the coefficients on forecast levels are generally of the same signs as those reported by Romer and Romer (2004), indicating tighter policy in response to stronger economic activity and higher prices. The inclusion of the capacity utilization and additional unemployment terms is also reflected in the regression $R^{2}$, which is higher than that for the original Romer and Romer (2004) specification (31\% as compared to $28 \%$ ). ${ }^{11}$

\footnotetext{
${ }^{10}$ See Federal Reserve (2005) or the International Banking Act of 1978 (the Humphrey-Hawkins Act).

${ }^{11}$ This may also reflect a reduction in the relative variability of the target federal funds rate over the years 19972006.
} 
Table 1: Policy Identification Regression

\begin{tabular}{|c|c|c|c|c|c|c|c|c|c|}
\hline & & coeff. & s.e. & t-stat. & & & & & \\
\hline & rcept & -0.8851 & 0.7846 & -1.128 & & Ob & ervations & $\mathrm{R} 2$ & DW \\
\hline Target from & last meeting & -0.0319 & 0.011 & -2.9034 & & & 346 & 0.3187 & 1.5066 \\
\hline Forecast & -1 & -0.0008 & 0.0102 & -0.0811 & Forecasted & -1 & -0.0545 & 0.1556 & -0.3502 \\
\hline Output & 0 & 0.0257 & 0.0269 & 0.9572 & Unemployment & 0 & 0.2025 & 0.3461 & 0.5852 \\
\hline Growth & 1 & -0.0144 & 0.0315 & -0.4565 & & 1 & 0.0544 & 0.5173 & 0.1051 \\
\hline & 2 & 0.0110 & 0.0328 & 0.335 & & 2 & -0.2387 & 0.3317 & -0.7198 \\
\hline & total effect & 0.0215 & 0.0285 & 0.7537 & & total effect & -0.0364 & 0.0283 & -1.2838 \\
\hline Ouput & -1 & 0.0087 & 0.0164 & 0.5305 & Unemployment & -1 & -0.1830 & 0.1871 & -0.9778 \\
\hline Growth & 0 & 0.0800 & 0.0315 & 2.5358 & Revision & 0 & -0.2920 & 0.3056 & -0.9555 \\
\hline Revision & 1 & -0.0141 & 0.0372 & -0.3791 & & 1 & 0.0006 & 0.4711 & 0.0013 \\
\hline & 2 & 0.0173 & 0.0396 & 0.4354 & & 2 & -0.0569 & 0.3348 & -0.17 \\
\hline & total effect & 0.0918 & 0.0622 & 1.475 & & total effect & -0.5312 & 0.1682 & -3.158 \\
\hline Forecasted & -1 & 0.0216 & 0.0226 & 0.9547 & Forecasted & -1 & 0.0477 & 0.0494 & 0.9658 \\
\hline Inflation & 0 & -0.0254 & 0.0288 & -0.8831 & Manufacturing & 0 & -0.0347 & 0.0504 & -0.6873 \\
\hline & 1 & 0.0483 & 0.0439 & 1.1003 & Capacity & 1 & 0.0000 & 0.0001 & 0.2252 \\
\hline & 2 & 0.0136 & 0.0459 & 0.2967 & Utilization & 2 & 0.0001 & 0.0008 & 0.0642 \\
\hline & total effect & 0.0581 & 0.0179 & 3.2372 & & total effect & 0.0131 & 0.0083 & 1.5853 \\
\hline Inflation & -1 & 0.0125 & 0.0288 & 0.4337 & Manufacturing & -1 & -0.0476 & 0.0494 & -0.9649 \\
\hline Revision & 0 & -0.0611 & 0.0378 & -1.616 & Capacity & 0 & 0.0901 & 0.0576 & 1.5643 \\
\hline & 1 & -0.0001 & 0.0526 & -0.0023 & Utilization & 1 & 0.0000 & 0.0001 & -0.5889 \\
\hline & 2 & 0.0047 & 0.0603 & 0.0787 & Revision & 2 & -0.0001 & 0.0005 & -0.1274 \\
\hline & total effect & -0.0440 & 0.0805 & -0.547 & & total effect & 0.0424 & 0.0294 & 1.4425 \\
\hline
\end{tabular}

Note: The sample is all scheduled FOMC meetings from the period $1969-2006$. See the main text for a description of the regressors. The total effects refer to the sum of the coefficients on sets of forecasts or forecast revisions for the previous, current and next two quarters.

In order for the regression residuals from equation (2) to capture exogenous monetary policy that is useful in the estimation of bank lending responses, we require that: (i) the Greenbook forecasts of output, inflation, unemployment, and capacity utilization are not a function of the change in the federal funds rate target; and, (ii) the Greenbook forecasts account for any changes to the target that are endogenous to factors that may influence bank lending via expected economic conditions. The first assumption rules out reverse causation in equation (2).

As remarked upon by Romer and Romer (2004), the Greenbook forecasts are generally formulated under the assumption that there is no change in policy stance at least until the FOMC meeting after the next, ruling out this possibility. The future path of policy underlying the Greenbook forecasts is assumed to be appropriate with the achievement of the FOMC's objectives (see Faust and Wright, 2008, for further detail about the Greenbook's policy rate conditioning assumptions). One caveat is that Greenbook forecasts can draw upon forwardlooking variables (e.g., asset prices, industry surveys) that embody market expectations over the 
policy change at the current meeting. In that case, our identification requires that output, inflation, unemployment and manufacturing capacity utilization respond to policy with a sufficiently long lag such that the forecasts in equation (2) are not subject to reverse causation.

The second assumption is crucial to exclude policy movements that may lead to biased estimates of bank level lending responses to monetary policy. The Greenbook forecasts are a natural means to achieving this objective because they represent the real-time information available to policy-makers and are known to perform well relative to alternative forecasts (see Romer and Romer, 2000, Romer and Romer, 2008, and Bernanke and Boivin, 2003, for evidence). ${ }^{12}$ Instances in which the controls in equation (2) may not eliminate policy movements that are endogenous to lending determinants occur when the Federal Reserve responds to banking sector conditions directly. If concerns over bank liquidity prompt the Federal Reserve to keep interest rates on hold even when Greenbook forecasts point to higher interest rates, a negative monetary policy change would be recorded. However, this may fail to stimulate lending growth if liquidity concerns prevent banks from doing new business. In terms of the present application, the banking crisis that followed the collapse of the sub-prime housing market in 2007 is excluded from the sample. However, two other relevant episodes are included in the sample: (i) the years surrounding the Basel I Accord (agreed in 1988 and implemented in 1992), which is often argued to have prompted bank balance sheet adjustment and a looser monetary policy than would otherwise have been the case (Ashcraft, 2006); and, (ii) the Federal Reserve Bank of New York's rescue of U.S. hedge fund Long-Term Capital Management (LTCM) in 1998, which may have induced similar effects. In section 5, we provide evidence that our core results are not affected by these episodes.

For any identification scheme, a natural question is: what are the sources of the policy shocks estimated from equation (2)? A key element is likely to be the idiosyncratic component of FOMC member interest rate choices. For example, even absent a future cyclical expansion, interest rates may be increased if FOMC members are concerned with their public reputation (Bluedorn and Bowdler, 2011, discuss a relevant example), possess a private forecast that points to an expansion that does not transpire (Romer and Romer, 2008), or hold a view of the economy that leads them to favor larger interest rate rises than might be warranted given the available forecasts (Romer and Romer, 2004). Alternatively, FOMC membership may change such that policymaker preferences favor tighter or looser policy irrespective of the cyclical position. In other situations, policymakers may feel obliged to validate market beliefs over policy, even when such beliefs are incorrect (Christiano, Eichenbaum and Evans, 1999). It is these federal funds

\footnotetext{
${ }^{12}$ It is of course possible that individual firms, consumers and banks have information concerning their future prospects (as opposed to general economic prospects) that is not reflected in the Greenbook. However, this will not lead to estimation bias provided that FOMC decisions regarding the target federal funds rate are not correlated with such information. In essence, it must be the case that any determinant of monetary policy decisions (e.g., the views of an influential FOMC member) does not contain information for loan supply and loan demand beyond that in the Greenbook.
} 
rate adjustments, driven by errors and preference shifts, that we use to obtain estimates of bank lending responses to monetary policy.

The data on bank lending that we use in our empirical work are reported on a quarterly basis. Thus, monetary policy changes defined at the frequency of FOMC meetings, which currently take place eight times per annum, must be aggregated to the quarterly frequency. The appropriate method of aggregation depends critically on whether the data to be studied are measured on a quarter-average or quarter-end basis (see Bluedorn and Bowdler, 2011, for relevant discussion). In the present application, bank-level data are drawn from end-of-quarter reports filed with the Federal Deposit Insurance Corporation (FDIC). Balance sheet data are reported for the final day of a quarter and banks have up to 30 days in the following quarter to confirm the figures reported. To parallel this treatment, we construct a quarterly series for exogenous monetary policy by cumulating the post-meeting identified monetary policy changes at a daily frequency within a particular quarter, to give a variable that we denote UM. ${ }^{13}$ This method is equivalent to defining a daily interest rate level from the cumulated value of all past identified policy changes and taking the change in the level from the final day of the previous quarter to the final day of the current quarter. Accordingly, we use precisely that method to obtain analogous quarterly changes in the effective federal funds rate, denoted FF. ${ }^{14}$ In Figure 1, we present time series plots for UM and FF. During the sample 1969q2 to 2006q4 the standard deviation of UM is 57 basis points and that of FF is 204 basis points, suggesting that roughly three quarters of the variation in the effective federal funds rate is eliminated from UM as part of the identification procedure. The correlation of the two series is 0.57 .

\footnotetext{
${ }^{13}$ To see the importance of consistent end-of-period measurement of balance sheet variables and monetary policy measures, suppose that lending responds in full to monetary policy within a month. It is then the case that a monetary policy shock in the third month in a quarter changes lending by the same amount as a shock observed in the first, even though a period average interest rate change would be smaller in the first scenario than in the second. The estimated effect of monetary policy on lending growth would then be distorted.

${ }^{14}$ The daily effective federal funds rate data come from the FRED database maintained by the Federal Reserve Bank of St. Louis.
} 
Figure 1: Endogenous and Exogenous Monetary Policy Shocks

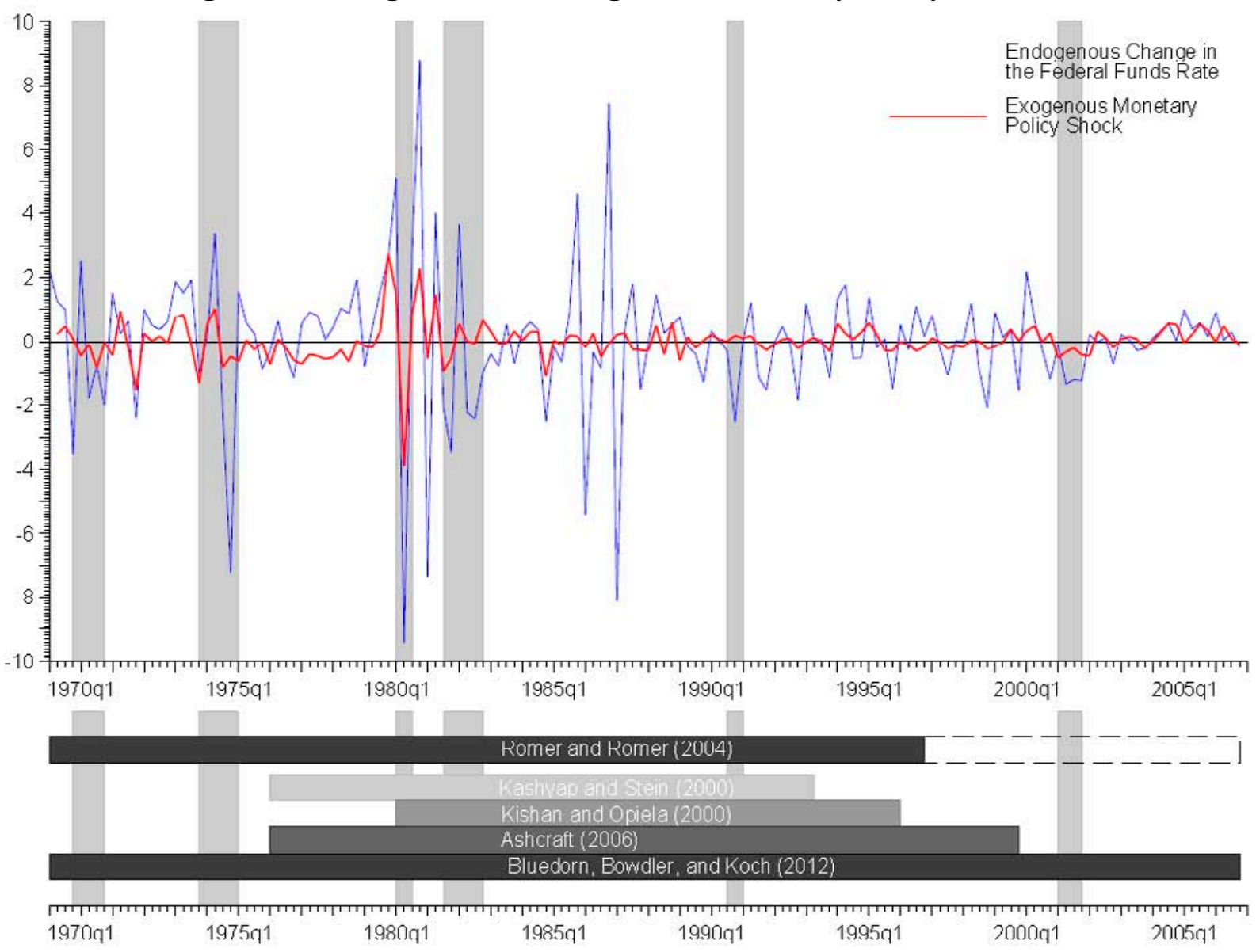

\section{B. Regression Specification}

To evaluate bank lending responses to monetary policy, we estimate regression models of the form:

$$
\begin{aligned}
\Delta L_{i, t}= & \alpha+\sum_{l=1}^{4} \rho_{l} \Delta L_{i, t-l}+\sum_{m=1}^{3} \sum_{l=0}^{4} \beta_{m, l} M_{m, t-l}+\sum_{k=1}^{5} \gamma_{k} B_{k, i, t-1} \\
& +\sum_{m=1}^{3} \sum_{k=1}^{5} \sum_{l=0}^{4} \delta_{m, k, l} B_{k, i, t-1} M_{m, t-l}+\mu t+\sum_{q=1}^{3} \phi_{q} S_{q}+\varepsilon_{i, t}
\end{aligned}
$$

where $i$ indexes banks, $t$ indexes time in quarters, $\Delta L_{i, t}$ denotes the percentage growth of total loans measured at current prices, $M$ is a vector of $m=3$ macroeconomic variables (described below), $B$ is a vector of $k=5$ bank characteristics (described below), $S_{q}$ is a set of seasonal dummy variables equal to 1 in quarter $q$ and zero otherwise, and $\varepsilon$ is a mean-zero error term.

The components of vector $M$ are:

1. a monetary policy measure, either $\mathrm{UM}$ or $\mathrm{FF}$, as described in section 2;

2. real GDP growth in percentage points; 
3. growth in the PCE core price index in percentage points.

We present two versions of the regressions: (i) a less noisy version based on yearover-year percentage growth in lending $\left(\Delta L_{i, t}\right)$ and the non-policy macroeconomic controls and (ii) one version based on annualized quarter-over-quarter percentage growth in lending $\left(\Delta L_{i, t}\right)$ and the non-policy macroeconomic controls.

The vector of $B$ bank characteristics comprises:

1. the natural log of bank assets in millions of dollars, at current prices;

2. an indicator variable set to unity post-1986 if a bank is part of a bank holding company and zero otherwise (following Ashcraft (2006) this characteristic is dated $t$ rather than $t-1) ;^{15}$

3. the ratio of bank securities to assets;

4. the ratio of total equity capital to assets;

5. the ratio of cash to assets.

For the interaction terms, the components of $M$ are broken out (denoted $M_{m, t}$ for $m \in\{1,2,3\})$. We give the exact variable definitions and data sources in section 3.C.

The regression specification in equation (3) is closely related to those employed by Ashcraft (2006) and Loutskina (2011). Once-lagged bank characteristics are included as controls, to allow for differences in lending growth conditional upon bank size, holding company affiliation, and balance sheet composition. The growth and inflation controls in the vector $M$ account for variations in nominal lending growth arising from contemporaneous changes in prices and economic activity. Interactions between the macroeconomic variables and bank characteristics capture heterogeneity in bank lending responses to monetary policy, income growth, and inflation.

There are three points that we highlight in relation to equation (3). First, the interactions between macroeconomic variables and bank characteristics feature measures of characteristics dated $t-1$, except in the case of the bank holding company dummy which is dated $t$. As such, lending decisions in period $t$ are conditional on characteristics that are pre-determined. They are thus less likely to be influenced by current lending behavior (the bank holding company indicator is not pre-determined, but it is not derived from the bank balance sheet). This structure mirrors that in Ashcraft (2006) and Loutskina (2011). A natural alternative would be to date interacted characteristics $t-\ell-1$ such that they are also pre-determined with respect to the monetary

\footnotetext{
${ }^{15}$ The indicator recognizes holding company status only in the post-1986 period, to reflect the inception of the Federal Reserve's source of strength doctrine, which underpins the interpretation of holding companies as credit networks through requiring that dominant holding company banks support their affiliates during periods of financial stress. Ashcraft (2008) shows that in practice, the functioning of internal capital markets improved significantly from 1989. However, we focus on the post-1986 period as in Ashcraft (2006).
} 
policy measure. We consider this case in our robustness tests in section 5. As we discuss there, the results change very little due to the fact that the variation in characteristics across quarters close in time is small relative to the cross-sectional variation in characteristics. ${ }^{16}$

Second, each of the bank characteristics ratios (except the binary variable for bank holding company status) are demeaned by sample quarter and normalized by the standard deviation. Nominal assets are additionally deflated by the GDP deflator. Thus, the first component of the vector $\sum_{\ell=0}^{4} \beta_{\ell}$ measures the percentage change in lending a year after a 100 basis point (b.p.) monetary policy contraction for an unaffiliated bank at the sample mean of each characteristic (this overlooks contributions from autoregressive terms, a point to which we return in section 4$)$. The $k^{\text {th }}$ component $(k \leq 5)$ of the vector $\sum_{\ell=0}^{4} \delta_{1, k, \ell}$ measures the increment to the marginal lending response to a monetary contraction $(m=1)$ when the $k^{\text {th }}$ characteristic is 1 standard deviation above the sample mean (or a bank is affiliated with a holding company in the case of that characteristic).

Third, in addition to the levels of real income growth and inflation, the regression includes a full set of interactions between those variables and bank characteristics. This ensures that heterogeneity in bank lending responses to monetary policy is estimated after controlling for: (i) purely nominal effects on lending growth from inflation; and, (ii) heterogeneity in the response of real lending growth to macroeconomic factors like current output growth and inflation. ${ }^{17}$

The final elements of the regression specification are a set of seasonal dummies and a time trend (although macro variables are seasonally adjusted, bank-level variables are not). The trend is included to deal with the fact that total assets (a bank characteristic) drifts through time whereas other variables are growth rates or ratios. ${ }^{18}$

The maximum lag order in the benchmark regression specification is 4, which is typical of micro bank lending regressions using quarterly data (see inter alia Kashyap and Stein, 2000, Ashcraft, 2006, and Loutskina, 2011). Lags in the dependent variable control for serial correlation in the data that is not eliminated by the control variables. Similar to Ashcraft (2006),

\footnotetext{
${ }^{16}$ While we consider characteristics that are pre-determined for the current lending response to monetary policy, we make no claim to have identified exogenous variation in characteristics. In line with most of the literature, we do not model bank characteristics. The determinants of characteristics may include the properties of previous monetary policy regimes, raising the possibility that the effects of policy on bank lending are more complex than our estimates indicate. It could even be the case that past values of a bank characteristic are endogenous to current monetary policy (e.g., via an expectations effect). Any resulting estimation biases are likely to be less important in the case of UM than in the case of FF, because the former is less easily predicted due to its orthogonality to economic forecasts.

${ }^{17}$ Inflation may affect real lending volumes if loan contracts are not fully inflation-indexed.

${ }^{18}$ Given the short time series for some panels, we do not undertake a full unit-root analysis.
} 
we calculate all regression standard errors through clustering at the bank-level to deal with any residual heteroscedasticity and autocorrelation of unknown form. ${ }^{19}$ One source of uncertainty that our standard errors do not take into account is the first stage regression used to identify UM. However, Pagan (1984) demonstrated that this uncertainty only affects inference based on nonzero null hypotheses - inference based on zero null hypotheses remains valid.

\section{Data}

\section{Bank-Level Data}

Our bank-level data are from the Reports of Condition and Income ("Call Reports") usually submitted to the FDIC at the end of each quarter by all insured banks in the United States. ${ }^{20}$ One major contribution of this paper is an extension of the banking level sample back to 1968, and up to 2006 (Figure 2). In order to prevent window-dressing, historically U.S. commercial banks were "called" at surprise dates. Banks have reported consistently exactly at the end of the quarter only from 1975. Thus, for the beginning of the sample prior to 1975 there are some irregularities. Figure 3 shows the regular benchmark timing in the bottom and the actual call dates in the top of the panel. As you can see, there are some minor irregularities, for instance the dates varies slightly by some business days around the end of the quarter and for some instances reporting is semi-annual rather than quarterly. Two additional assumptions are necessary in order to make good use of that earlier data. First, we assume that the timing does not matter and merely induces measurement error in the variables that is not a function of any of the other controls (Figure 4). Second, we interpolate bank level variables for the few quarters that data were missing, inducing measurement error in both the dependent and independent variables (Figure 5). Again, as long as these are not systematically related to other controls this merely increases the variance of the estimators.

Otherwise, the variable definitions that we outline follow those used in Ashcraft (2006). The Call Report line numbers used to generate individual series are provided in Kashyap and Stein (2000).

The dependent variable is derived from a series for total loans minus allowances for loan losses. It includes loans under commitment for some period (predominantly lines of credit to firms), as well as loans on flexible terms. ${ }^{21}$ The correction for loan losses allows for the fact that

\footnotetext{
${ }^{19}$ Wooldridge (2003) notes the importance of clustering in panels that explain micro responses to macro shocks, as in the present case.

${ }^{20}$ We are grateful to Adam Ashcraft for providing a dataset containing variables constructed from these sources using guidelines proposed by Kashyap and Stein (2000). Some series are dropped from the Call Reports during the period considered, while others are added. See Kashyap and Stein (2000) for notes on how such changes were handled.

${ }^{21}$ The data include international lending from 1978 onwards.
} 
a bank may reduce its loan book by writing off bad loans, as well as through varying the supply of new credit. However, as discussed by Ashcraft (2001) and Peek and Rosengren (1998), our measure of loans does not control for loans being moved off bank balance sheets via securitization. In our case, distortions to lending growth via securitization should be limited since our sample ends in 2006. This includes only a few years of the period of growth in the market for mortgage-backed securities which started in the mid-1990s. Any data distortions from securitization should be minimized for this sub-sample, since relatively few loans from this category are securitized (Loutskina, 2011).

\section{Figure 2: Macroeconomic Controls During the Sample}

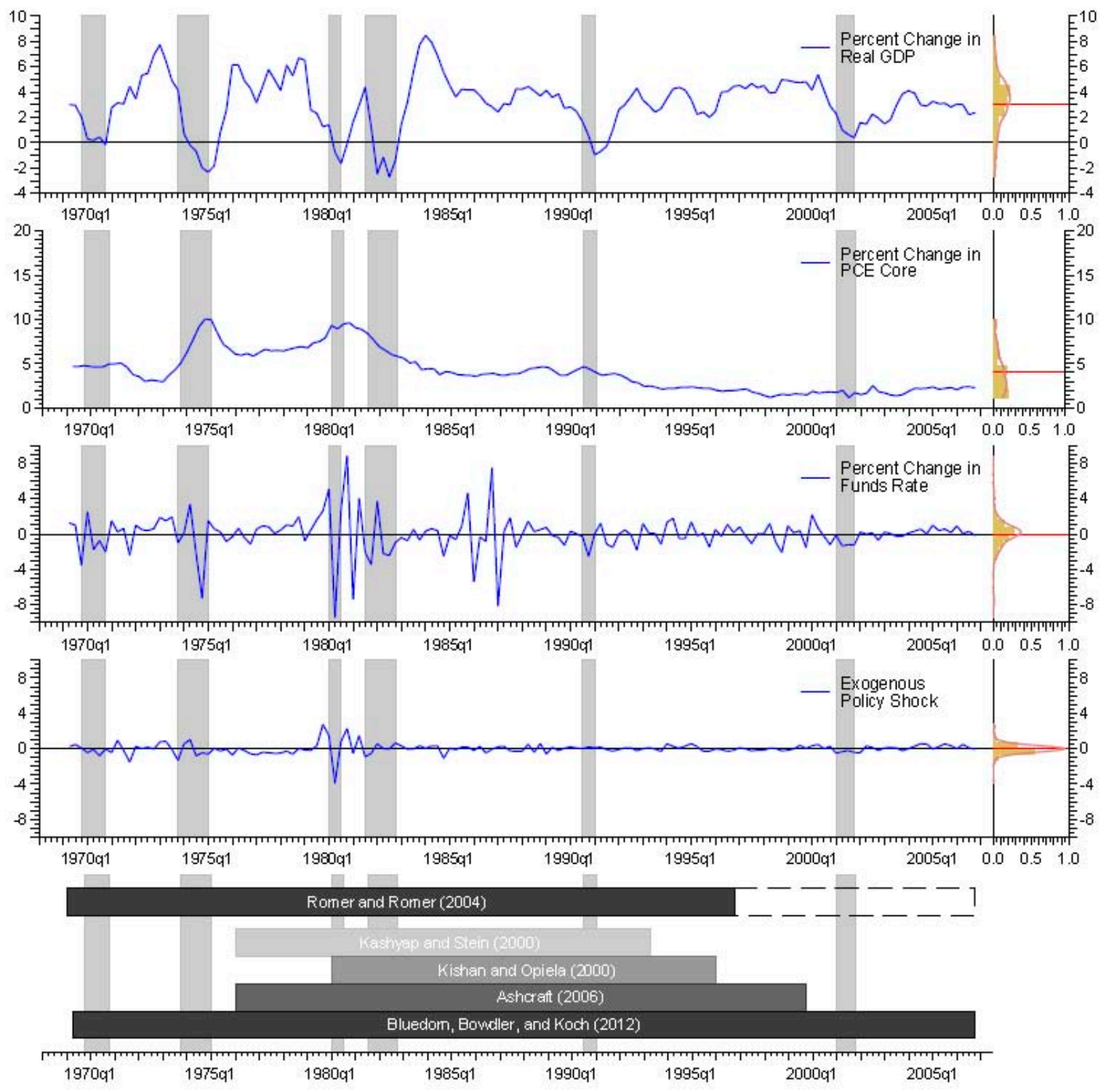


Figure 3: Imperfectly Measured Variables Prior to 1975

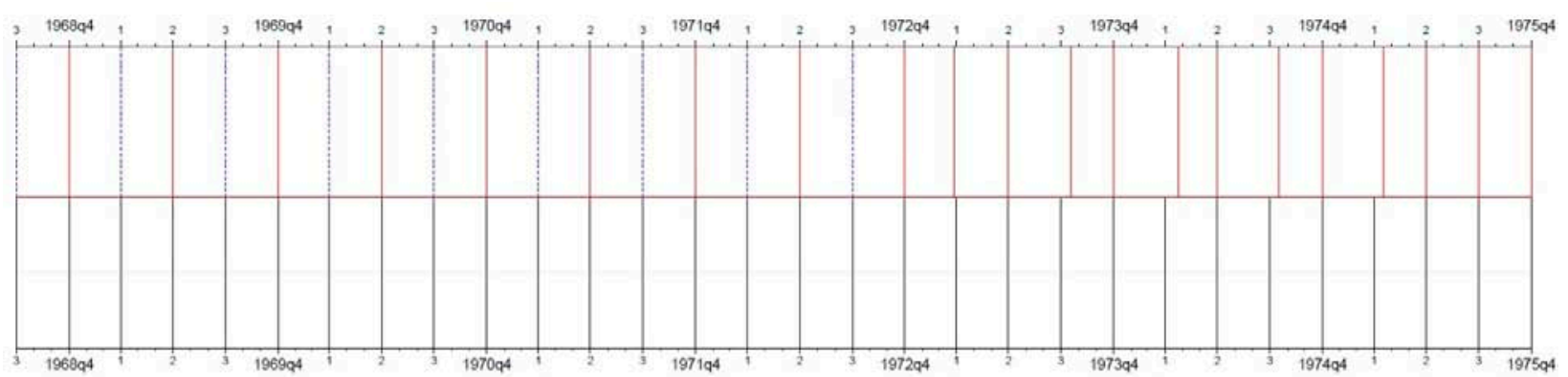

Figure 4: Assumptions Regarding Timing Imperfectly Measured Variables

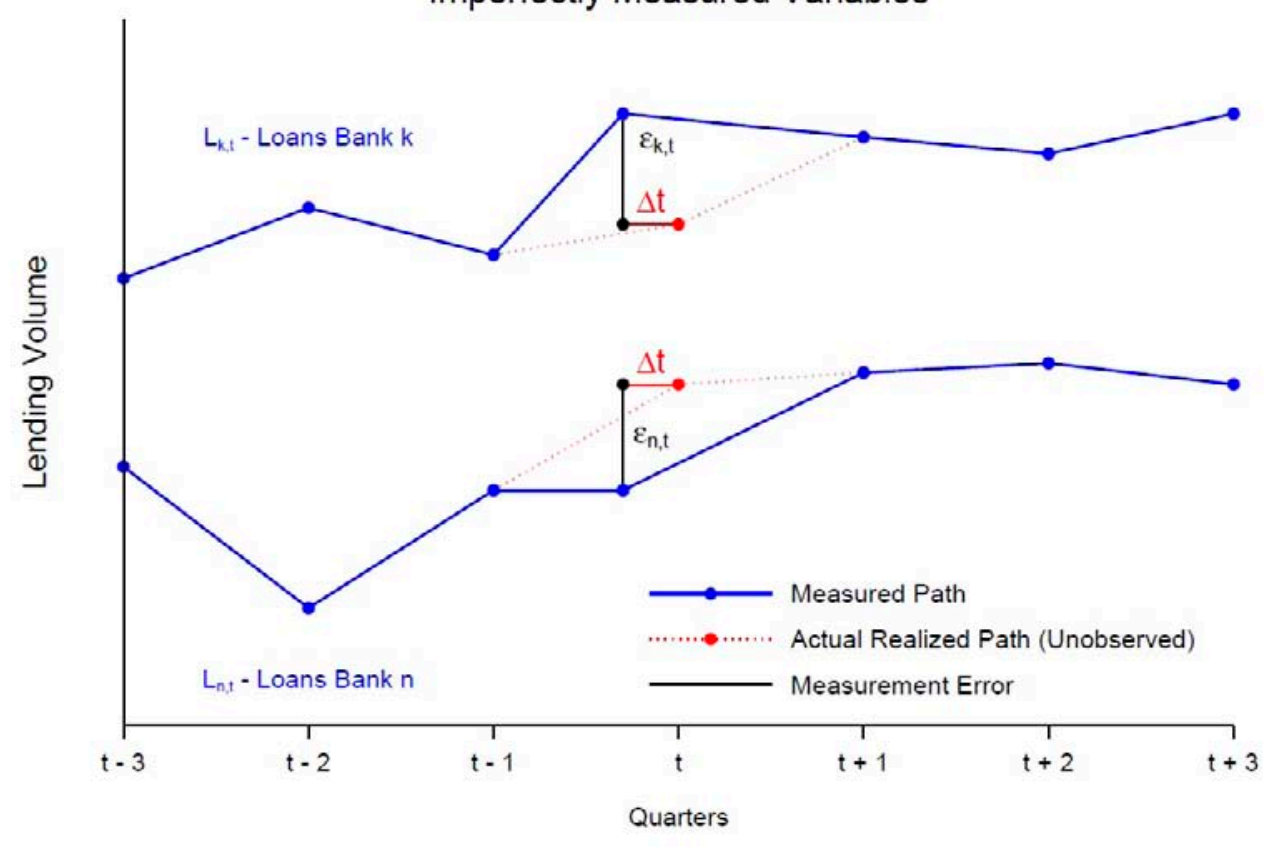

CInternational Monetary Fund. Not for Redistribution 
Figure 5: Assumptions Regarding Interpolation

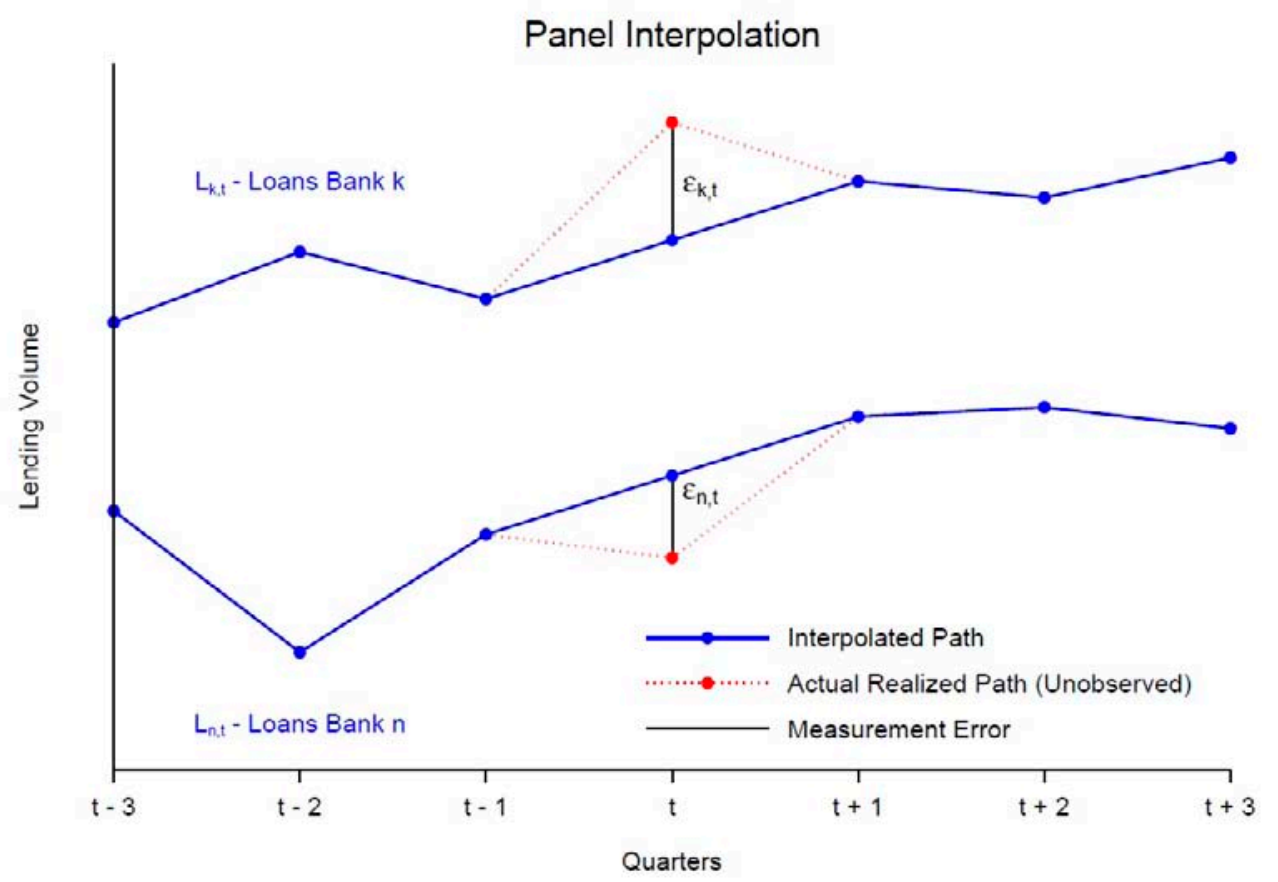

Total bank assets are reported net of loan loss reserves and form the basis for measuring balance sheet composition, across securities, equity capital and cash (each of these terms is measured relative to total assets). Bank securities are the sum of Total Investment Securities and Assets Held in Trading Accounts. Total Equity Capital is the book value of equity issued plus the cumulated value of retained earnings. Cash is cash on the asset side of the balance sheet. ${ }^{22}$ The indicator for bank holding company status is taken from Ashcraft (2006), who identifies holding companies from sets of banks that have the same regulatory holder identification number.

The dataset used for our baseline estimations is an unbalanced quarterly panel spanning $1969 q 3$ to $2006 q 4$. It features a maximum of 15,306 banks and a minimum of 7,922 banks. The average number of observations per bank is 112 quarters or about 28 years. In line with other studies, this sample is obtained after excluding bank/quarter observations affected by mergers, since they may induce spurious movements in balance sheet variables (following a merger the merged banks are dropped and a new bank enters the dataset. ${ }^{23}$

\footnotetext{
${ }^{22}$ Each of the balance sheet characteristics are affected by the fact that prior to 1984, aggregates for certain asset and liability classes are not reported. They are therefore proxied through summing their relevant sub-components. For example, through 1983, Total Investment Securities is proxied by the sum of securities on the balance sheet from different issuers. See Kashyap and Stein (2000) for a full discussion.

${ }^{23}$ Due to consolidation of the banking sector, the number of banks falls to roughly 8,000 by the end of the sample see Table 2.
} 
In order to deal with other exceptional movements in the data, we follow Ashcraft (2006) in fitting our benchmark regression by OLS for the largest possible sample and then eliminating outliers. These are defined as observations for which the absolute DFITS statistic (the scaled difference between the fitted values for the $n^{\text {th }}$ observation when the regression is fitted with and without the $n^{\text {th }}$ observation) exceeds the threshold $2 \cdot \sqrt{K / N}$, where $K$ is the total number of explanatory variables and $N$ is the overall sample size (Welsch and Kuh, 1977). The number of observations excluded depends on whether the regression is fitted using UM or FF. Specifically, from a total sample of 1,724,924 observations the outlier exclusion reduces the sample to $1,724,355$ observations when UM is the policy measure and 1,724,334 observations when FF is the policy measure. ${ }^{24}$ These differences are minor in the context of the sample size. We emphasize that our results across UM and FF do not depend on outlier exclusion. The comparisons presented in the next section are observed when using either the full or trimmed samples.

In Table 2, we report summary statistics for the bank-level variables. Summary statistics are calculated using data from four years corresponding to the end of each decade $(1970,1980$, 1990, and 2000), for all banks in the baseline estimation sample. An inspection of these statistics supports our treatment of the series as stationary, with the exception of the total assets measure (see the discussion in section 3.B).

\section{Macroeconomic Data}

The series for income growth is constructed from seasonally adjusted real GDP, and that for the inflation rate is from the seasonally adjusted personal core consumption expenditure price index (PCE). Both series are from the U.S. Bureau of Economic Analysis (BEA) and were extracted from the Federal Reserve Bank of St. Louis's FRED database. The output and price data are period average values. They refer to a flow of transactions within a particular quarter, whereas our bank-level data are end-of-quarter values from stock concepts on balance sheet statements. Unlike the interest rate series, for which we can examine data for the final day from a particular quarter, there are no end-of-period concepts for output and prices. This measurement mismatch could in theory limit the extent to which current output and inflation control for the endogeneity of the federal funds rate. Apart from these two non-policy variables, two different policy controls FF and UM were described in section 3.B. Figure 2 displays time-series and data summaries of all macroeconomic controls.

\footnotetext{
${ }^{24}$ The outlier exclusion procedure offers some robustness against certain changes to variable definitions that occur during the sample which are documented by Kashyap and Stein (2000).
} 
Table 2: Bank Level Summary Statistics

\begin{tabular}{|c|c|c|c|c|c|c|c|c|}
\hline & \multicolumn{2}{|c|}{1970} & \multicolumn{2}{|c|}{1980} & \multicolumn{2}{|c|}{1990} & \multicolumn{2}{|c|}{2000} \\
\hline & Mean & Std. Dev. & Mean & Std. Dev. & Mean & Std. Dev. & Mean & Std. Dev. \\
\hline Loan Growth & 10.5589 & 23.2026 & 4.5732 & 16.6064 & 9.834 & 34.5314 & 15.6723 & 38.1374 \\
\hline Assets & 46,670 & 496,413 & 139,751 & $1,735,830$ & 288,878 & $2,496,265$ & 778,952 & $10,220,686$ \\
\hline Holding Company Status & 0.1549 & 0.3618 & 0.3310 & 0.4706 & 0.6883 & 0.4632 & 0.7558 & 0.4296 \\
\hline Loans/Assets & 0.4809 & 0.1100 & 0.5407 & 0.1147 & 0.5475 & 0.1574 & 0.6286 & 0.1440 \\
\hline Deposits/Assets & 0.8892 & 0.0305 & 0.8839 & 0.0424 & 0.8828 & 0.0774 & 0.8321 & 0.0937 \\
\hline Securities/Assets & 0.3433 & 0.1173 & 0.2822 & 0.1163 & 0.2881 & 0.1546 & 0.2513 & 0.1360 \\
\hline Equity Captial/Assets & 0.0821 & 0.0244 & 0.0855 & 0.0246 & 0.0867 & 0.0434 & 0.1039 & 0.0462 \\
\hline Cash/Assets & 0.1231 & 0.0570 & 0.0923 & 0.0550 & 0.0715 & 0.0536 & 0.0490 & 0.0418 \\
\hline Number of Banks & \multicolumn{2}{|c|}{$13,195.00$} & \multicolumn{2}{|c|}{$14,351.00$} & \multicolumn{2}{|c|}{$12,365.00$} & \multicolumn{2}{|c|}{$8,309.00$} \\
\hline
\end{tabular}

Note: * Q4 of each year

Source: FFIED Call Reports. 


\section{EMPIRICAL RESULTS}

In Table 3, we present $\sum_{l=0}^{L} \beta_{l}$ for $L \in\{0,1,2,3,4\}$ and their associated standard errors for the two policy measures UM and FF. These statistics measure the percentage change in lending at various horizons following a 100 b.p. tightening at a bank that has the sample average balance sheet characteristics and is not affiliated with a holding company (we refer to such a bank as the representative bank). The full lending response also depends on the autoregressive parameters, but each of these is small (less than 0.1) and virtually identical across UM and FF versions of the regression. As such, they do not affect our inferences. We follow Kishan and Opiela (2000), Loutskina (2011) and Ashcraft (2006) in reporting the direct effect of policy on lending.

At each of the horizons considered, the lending reduction estimated from an exogenous monetary policy contraction exceeds that from a policy contraction measured by the realized federal funds rate. Furthermore, the precision associated with our estimates is such that $95 \%$ confidence intervals for the two estimates are non-overlapping at all horizons beyond the current quarter. The inertia in aggregate lending estimated from FF has been attributed to factors such as loans under commitment, which may thwart the withdrawal of bank credit to firms - see Bernanke and Blinder (1992), Morgan (1998) and Kishan and Opiela (2000). While such a possibility is plausible, our estimates suggest that at least part of the sluggishness in bank lending behavior is attributable to policy changes that are endogenous to other macroeconomic fundamentals. Controlling for extraneous loan demand and loan supply movements that may be linked to these fundamentals reveals quantitatively more important monetary transmission mechanism via credit markets.

Table 3: Comparison of Dynamic Lending Response of a Representative Bank

\begin{tabular}{|c|c|c|c|c|}
\hline \multirow[b]{2}{*}{ Horizon } & \multicolumn{2}{|c|}{ YoY } & \multicolumn{2}{|c|}{ QoQ } \\
\hline & UM & FF & UM & FF \\
\hline 0 & -0.3068 & -0.1360 & -0.3240 & -0.1125 \\
\hline s.e. & 0.0490 & 0.0177 & 0.0727 & 0.0328 \\
\hline 1 & -0.9060 & -0.4259 & -2.0864 & -0.8077 \\
\hline s.e. & 0.0810 & 0.0396 & 0.1133 & 0.0697 \\
\hline 2 & -1.9893 & -0.8124 & -3.7095 & -1.6786 \\
\hline s.e. & 0.1342 & 0.0690 & 0.1607 & 0.1070 \\
\hline 3 & -2.5439 & -1.1207 & -4.5173 & -2.3476 \\
\hline s.e. & 0.1650 & 0.0916 & 0.2164 & 0.1357 \\
\hline 4 & -3.2841 & -1.4813 & -5.2595 & -3.0291 \\
\hline s.e. & 0.1960 & 0.1068 & 0.2686 & 0.1521 \\
\hline
\end{tabular}




\section{A. Effects of Bank Size and Holding Company Status}

In Table 4, we report the sums of cross effects between monetary policy and bank characteristics through horizon 4 (labeled interaction) when characteristics are set at 1 standard deviation of their sample distribution (except in the case of the holding company indicator which is set to unity). Sums of coefficients for other horizons are not reported given space constraints. However, they are consistent with the UM/FF comparisons developed below. To provide some context for our results, we also reproduce the horizon 4 lending response for the representative bank, as seen in Table 3. We consider the marginal lending response to a 100 b.p. policy contraction for a bank that is one standard deviation above the sample mean for each of the characteristics considered. This is the sum of the response at the representative bank and the interaction effect for a particular characteristic. ${ }^{25}$

We first focus on the results for total assets and the bank holding company indicator. In both cases, the sums of the interaction terms are positive, indicating that the characteristics help banks shield their lending growth from policy contractions. These effects are much larger when monetary policy is measured using UM as opposed to FF. Controlling for the endogeneity of monetary policy implies not only more powerful lending responses at the representative bank, but also a greater dispersion in lending responses across the population of banks. This is consistent with our argument in section 2 that lending responses to the endogenous drivers of policy likely correlate with bank characteristics. In the present case, it appears that lending by small banks and banks not affiliated with holding companies is more responsive to factors like expected economic growth, such that lending responses to monetary policy are attenuated to a greater extent amongst banks exhibiting such characteristics. As discussed in section 2, a possible reason for this is that cyclical upturns provide access to finance that is used more intensively by banks that cannot access other sources of funds.

The findings have important implications. Ashcraft (2006) argues that the composition of loan demand by borrower size and creditworthiness varies relatively little with holding company status, especially when compared with other characteristics such as total assets and leverage. Therefore, heterogeneity in lending responses associated with holding company status is more readily interpreted as evidence for differential loan supply responses of the sort predicted by the theory of the bank lending channel. The more powerful holding company effect estimated from the exogenous policy measure raises the possibility that the lending channel is quantitatively more important than previously believed.

\footnotetext{
${ }^{25}$ In the case of the bank holding company indicator, the marginal effect is calculated for a bank that belongs to a holding company.
} 
Table 4: Heterogeneity in Lending Responses due to Bank Characteristics

\begin{tabular}{|c|c|c|c|c|c|}
\hline & & & \multirow{2}{*}{\multicolumn{2}{|c|}{ QoQ }} \\
\hline & & \multicolumn{2}{|c|}{ YoY } & & \\
\hline & & UM & $\mathbf{F F}$ & UM & $\mathbf{F F}$ \\
\hline \multirow[t]{2}{*}{ Representative Bank } & marginal effect & -3.2841 & -1.4813 & -5.2595 & -3.0291 \\
\hline & s.e. & 0.1960 & 0.1068 & 0.2686 & 0.1521 \\
\hline \multirow[t]{4}{*}{ Holding Company Status } & interaction & 5.5366 & 2.7783 & 11.0919 & 5.8506 \\
\hline & s.e. & 0.4644 & 0.2188 & 0.7927 & 0.3286 \\
\hline & marginal effect & 2.2526 & 1.2970 & 5.8324 & 2.8215 \\
\hline & s.e. & 0.3971 & 0.1815 & 0.7730 & 0.3237 \\
\hline \multirow[t]{4}{*}{ Assets } & interaction & 1.0616 & 0.0954 & 2.1983 & 0.4704 \\
\hline & s.e. & 0.1702 & 0.0891 & 0.2681 & 0.1424 \\
\hline & marginal effect & -2.2225 & -1.3859 & -3.0612 & -2.5587 \\
\hline & s.e. & 0.2225 & 0.1453 & 0.3944 & 0.2168 \\
\hline \multirow[t]{4}{*}{ Securities Ratio } & interaction & -1.1357 & -0.0443 & -1.8226 & 0.1723 \\
\hline & s.e. & 0.1453 & 0.0853 & 0.3593 & 0.1889 \\
\hline & marginal effect & -4.4197 & -1.5256 & -7.0822 & -2.8567 \\
\hline & s.e. & 0.2578 & 0.1027 & 0.4589 & 0.2265 \\
\hline \multirow[t]{4}{*}{ Cash Ratio } & interaction & 0.4139 & 0.0249 & 0.9812 & 0.0987 \\
\hline & s.e. & 0.1656 & 0.0906 & 0.3800 & 0.2331 \\
\hline & marginal effect & -2.8701 & -1.4564 & -4.2783 & -2.9304 \\
\hline & s.e. & 0.2462 & 0.1446 & 0.5116 & 0.2997 \\
\hline \multirow[t]{6}{*}{ Equity Capital Ratio } & interaction & 0.0177 & -0.2723 & -0.3038 & -0.7378 \\
\hline & s.e. & 0.4510 & 0.2837 & 1.0384 & 0.7046 \\
\hline & marginal effect & -3.2664 & -1.7536 & -5.5633 & -3.7669 \\
\hline & s.e. & 0.5462 & 0.3511 & 1.1313 & 0.7828 \\
\hline & $\mathrm{R} 2$ & 0.4603 & 0.4627 & 0.0066 & 0.0067 \\
\hline & Observations & $1,737,581$ & $1,750,726$ & $1,762,369$ & $1,775,773$ \\
\hline
\end{tabular}

Note: The reported lending responses are the sum of contemporaneous and four lagged responses to a 100 basis points policy tightening. Interaction effects are calculated for a bank one standard deviation above the quarter sample average for a characteristic. Standard errors obtained after clustering at the bank level are reported in parenthesis. ${ }^{* *}$ and $*$ indicate significance at the 1 and 10 percent levels respectively. 
As discussed by Ashcraft (2006), an important caveat is that although unaffiliated banks may be subject to a lending channel, the borrowers turned away from such banks may be accommodated by bank holding company networks, whose funds fill the gap in the market. The aggregate lending channel of monetary policy could then be weak or non-existent. Our estimates based on the year-over-year changes indicate that after an exogenous policy contraction the representative unaffiliated bank reduces lending 3.28 percentage points in the first year, while the representative affiliated bank raises lending 2.25 percentage points over the same period. This evidence is consistent with a redistribution of lending in the aftermath of shocks to bank funding. ${ }^{26}$ To investigate whether the countervailing loan responses offset at the aggregate level, we re-estimated our baseline regression after excluding all terms from the vector of bank characteristics $B$, to obtain the marginal effect of a policy tightening for a bank at the sample average of all characteristics, including holding company status. The lending reduction from UM (standard error in parentheses) is 1.85 percentage points $(0.14)$ and that from FF is 0.19 percentage points $(0.06)$ in the year-over-year empirical model. Thus, despite the compensating effect from affiliated banks, it appears that an aggregate transmission mechanism exists. Furthermore, this mechanism is twice as strong when estimated from UM.

The much sharper heterogeneity in bank lending behavior from UM may help explain two important features of the aggregate transmission mechanism. These are: (i) the different effects of policy across regions and industries (Carlino and Defina, 1998); and, (ii) a possible trend towards weaker propagation of monetary policy in recent decades (Boivin and Giannoni, 2002). Ashcraft (2006) presents weak evidence that state level lending responses to federal funds rate rises depend on the proportion of loans issued by affiliated banks. However, he finds that similar effects do not carry over to state income responses. The larger cross effects that we estimate from exogenous monetary policy suggest that much more of the heterogeneity in the aggregate effects of monetary policy may be attributable to banking sector structure than previous estimates suggest. Similarly, our results suggest that there is more scope for banking sector consolidation and the growth of bank holding companies to account for possible trends towards a weaker aggregate monetary transmission mechanism in recent decades. ${ }^{27}$ The

\footnotetext{
${ }^{26}$ These estimates are from our baseline regression specification, which contrasts affiliated and non-affiliated banks, assuming all other characteristics remain unchanged. It is of course possible that the switch to bank holding company status is associated with changes to other bank characteristics that affect bank lending responses at the margin. However, if we exclude all bank characteristics other than holding company status, to estimate the unconditional effect of affiliation, the finding that holding company banks raise lending at the expense of standalone banks remains intact.

${ }^{27}$ A caveat should be noted in relation to the interaction effect based on bank assets. Our assertions rest on interpreting the differential effects by bank assets in terms of loan supply. Ashcraft (2006) argues convincingly that the slope of the loan demand curve varies with bank assets (larger banks trade with customers whose loan demand is less interest rate sensitive). Therefore, part of the interaction between monetary policy and assets that we estimate could reflect heterogeneity in loan demand. It is less clear that such a feature of lending markets could drive heterogeneity in the aggregate transmission mechanism. We implicitly assume that at least part of the asset-based interaction arises from loan supply effects.
} 
relevance of these conjectures depends on the precise configuration of banking sector characteristics. Specifically, a region or episode associated with a banking sector dominated by holding companies must not be associated with other characteristics that reverse the impact of holding company affiliation on lending responses. We hope to address these questions in future research.

\section{B. Effects of Balance Sheet Composition}

The most striking result that we present in Table 4 relates to the securities-to-assets ratio. Following a 100 b.p. increase in the exogenous policy measure, a bank with securities one standard deviation above the mean reduces lending by a further 1.14 percentage points compared to the representative bank in the year-over-year model and by a further 1.82 percentage points in the quarter-over-quarter model. In contrast, following a 100 b.p. increase in the realized federal funds rate, a bank with securities one standard deviation above the mean has no meaningful shielding effects in the year-over-year model and shields lending by 0.17 percentage points relative to the average bank in the quarter-over-quarter model. However, the latter effect is not significant at the $10 \%$ level. In previous work, the shielding effect from securities has been related to the idea that such holdings are a buffer stock of liquid assets which can be used to substitute lost reserves during policy contractions (Kashyap and Stein, 2000, and Ashcraft, 2006). Our results suggest the empirical support for such an interpretation comes from a confounding of expected future growth and inflation with the monetary policy stance.

A possible explanation for the negative effect of monetary policy tightening upon lending for banks with large securities-to-assets ratios follows. An exogenous rise in interest rates is likely to raise the long end of the yield curve and depress securities prices, such that banks suffer a capital loss - see Bernanke and Gertler (1995) for a discussion of this effect. Banks with greater exposure to capital losses on securities will be forced to contract lending more aggressively, leading to an amplification effect. In such instances, seemingly liquid assets such as securities exhibit low "market liquidity", in the sense that their market value is driven below their fundamental value. As a result, banks may refrain from liquidating the assets and instead choose to contract their lending.

In marked contrast cash holdings of a bank do shield banks from monetary contraction with estimates of the shielding effect for a bank that is one standard deviation above the mean in terms of its cash holding ranging from 0.41 in the year-over-year model to 0.98 percentage points in the quarter-over-quarter model. The final row in Table 4 relate to the equity capital. Surprisingly, equity capital neither shields nor amplifies lending bank lending responses to monetary shocks, which might be due to the fact that much of the heterogeneity due to bank capitalization is captured by interactions with macroeconomic proxies for real and nominal factors. 


\section{Stability of the Baseline Results}

An important issue in any study of monetary policy transmission to the banking sector is the temporal stability of the results - see Bernanke and Blinder (1992), Kashyap and Stein (2000) and Ashcraft (2006). In our sample, an important structural change may arise from the introduction of the source of strength doctrine (Ashcraft, 2006). ${ }^{28}$ The Federal Reserve Board issued a formal statement in April 1987 indicating that failure by a parent bank to inject liquidity into a financially distressed subsidiary when funds are available would be considered an unsafe banking practice. ${ }^{29}$

In section 3.B, we argued that from 1987 onwards membership in a bank holding company should affect lending responses to monetary policy. Our baseline results are consistent with this idea. In this sub-section, we take our analysis of the effects of the source of strength of doctrine one stage further. We interact each of the cross terms in $\sum_{m=1}^{3} \sum_{k=1}^{5} \sum_{l=0}^{4} \delta_{m, k, l} B_{k, i, t-1} M_{m, t-l}$ with the binary variable that is set to unity post-1986 for banks that belong to a holding company (excluding the cross term that already features the holding company indicator). These extra terms are added to our baseline regression in (3). In Table 5, we report interaction coefficients for policy measures and characteristics (similar to those in Table 4), in addition to the changes to the interaction coefficients associated with the start of the source of strength doctrine.

The key feature of the results is that the post-1986 changes to the interaction coefficients (amongst holding company banks) are of approximately equal magnitude but opposite sign to the main interaction effects (the one exception is the interaction of FF with bank assets). As such, the total effect of balance sheet related characteristics on lending responses to monetary policy, both exogenous and endogenous, is close to zero during the second half of the sample for affiliated banks (and recall that affiliated banks represent over two thirds of all banks in this period). During the late 1980s and the 1990s, the principal source of heterogeneity in lending responses to monetary policy is affiliation with a holding company, not balance sheet composition. The roles of security holdings in amplifying and cash in mitigating the effects of exogenous policy on lending growth, are quantitatively smaller from the late 1980s onwards because they are observed only amongst banks that cannot access the financing networks provided by holding

\footnotetext{
${ }^{28}$ Another source of structural change is the abolition of regulation Q, which restricted banks' ability to vary interest rates in order to attract deposits (a source of funding). The abolition of this restriction was largely implemented via the Monetary Control Act of 1980, and is therefore likely to induce heterogeneity in our results across a much shorter period than the source of strength doctrine. Due to the limitations in estimating heterogeneity in our results across a period of just three years or so, we do not address the effects of Regulation Q. If observations from this period exerted undue influence on the results, the outlier detection procedure we employ ought to diagnose them.

${ }^{29}$ Ashcraft (2008) shows that the Financial Institutions Reform, Recovery, and Enforcement Act of 1989 unexpectedly strengthened the source of strength doctrine. Given that this change occurred just two years after 1987, we do not allow for a further structural change in 1989.
} 
companies. In contrast, when affiliated banks face write-downs in securities prices or loan values following policy tightening, they are able to tap loanable funds within the network, thus shielding their lending growth.

\section{Table 5: Bank Holding Company Lending Responses}

\begin{tabular}{|c|c|c|c|c|c|}
\hline & & \\
\hline & & \multicolumn{2}{|c|}{ YoY } & \multicolumn{2}{|c|}{ Q०Q } \\
\hline & & UM & $\mathbf{F F}$ & UM & $\mathbf{F F}$ \\
\hline \multirow[t]{2}{*}{ Representative Bank } & marginal effect & -3.4154 & -1.5394 & -5.0797 & -3.1292 \\
\hline & s.e. & 0.204 & 0.11 & 0.2734 & 0.166 \\
\hline \multirow[t]{2}{*}{ Holding Company Status } & interaction with policy & 6.2261 & 3.0183 & 8.5255 & 5.398 \\
\hline & s.e. & 0.6826 & 0.3007 & 2.6354 & 0.5261 \\
\hline \multirow[t]{4}{*}{ Assets } & interaction with policy & 1.4369 & 0.1382 & 2.6568 & 0.3424 \\
\hline & s.e. & 0.1764 & 0.1193 & 0.2989 & 0.1762 \\
\hline & with policy and holding company & -0.9142 & 0.0089 & -3.1439 & -0.7028 \\
\hline & s.e. & 0.5205 & 0.2135 & 0.8637 & 0.3737 \\
\hline \multirow[t]{4}{*}{ Securities Ratio } & interaction with policy & -1.5012 & -0.0551 & -2.2442 & 0.0476 \\
\hline & s.e. & 0.1791 & 0.1045 & 0.41 & 0.2398 \\
\hline & with policy and holding company & 1.3514 & -0.0949 & 2.049 & -0.0101 \\
\hline & s.e. & 0.4818 & 0.2185 & 1.3317 & 0.571 \\
\hline \multirow[t]{4}{*}{ Cash Ratio } & interaction with policy & 0.2837 & 0.0557 & 1.3405 & 0.0968 \\
\hline & s.e. & 0.1852 & 0.11 & 0.4265 & 0.2082 \\
\hline & with policy and holding company & 0.2215 & 0.0266 & -1.0476 & -1.2427 \\
\hline & s.e. & 0.5619 & 0.3043 & 1.7275 & 1.0053 \\
\hline \multirow[t]{6}{*}{ Equity Capital Ratio } & interaction with policy & 0.0073 & -0.4491 & 0.3627 & -1.3477 \\
\hline & s.e. & 0.4502 & 0.271 & 1.045 & 0.5221 \\
\hline & with policy and holding company & 2.1446 & 1.1781 & -14.5082 & -1.5695 \\
\hline & s.e. & 2.248 & 1.0711 & 12.886 & 1.9497 \\
\hline & R2 & 0.4435 & 0.452 & 0.0061 & 0.0063 \\
\hline & Observations & $1,737,141$ & $1,750,290$ & $1,757,740$ & $1,772,101$ \\
\hline
\end{tabular}

Note: The reported lending responses are the sum of contemporaneous and four lagged responses to a 100 basis points policy tightening. Interaction effects are calculated for a bank one standard deviation above the quarter sample average for a characteristic. Standard errors obtained after clustering at the bank level are reported in parenthesis. ${ }^{* *}$ and ${ }^{*}$ indicate significance at the 1 and 10 percent levels respectively. 


\section{ROBUSTNESS}

In this section, we report the results of robustness exercises performed for our baseline regression estimates presented in tables 3 and 4. First, in section 3 we noted that the policy measure UM may not eliminate endogenous policy movements during episodes in which the FOMC set interest rates in light of banking sector conditions. The episodes during which such a critique seems reasonable for our sample are: (i) the tightening of bank capital regulations due to the Basel I Accord, which may have induced less restrictive monetary policy than would have been implemented based on growth and inflation objectives alone; and, (ii) the Federal Reserve Bank of New York's rescue of the hedge fund LTCM in the late 1990s, which may have prompted a similar policy response. We define two separate dummy variables, one equal to unity for all quarters in the period 1990-1993 (Ashcraft, 2006, uses a similar dummy variable), and the second equal to unity for all quarters in 1998-1999 (the LTCM rescue occurred in 1998). We then interact these dummy variables with each of the terms from equation (3) that feature a monetary policy measure, and estimated the extended specification using the procedure outlined in section 3. The results from this exercise, for both UM and FF, are presented in the first column of Table 6 . The effect of monetary policy on lending growth at the representative bank increases in absolute size only marginally, indicating little evidence that the estimated effects of monetary policy were attenuated during the two episodes considered. The interaction coefficients are in line with those presented in Table 4, and the comparison of interaction effects across UM and FF supports each of the main results described in section 5.

In the second column in Table 6, we report results obtained after augmenting equation (3) with bank-level fixed effects. Although substantial fixed effects are unlikely given that we model loan growth rather than total loans, we consider this robustness exercise given that it has been applied elsewhere in the literature. For example, Loutskina (2011) motivates a fixed effects lending growth specification based on differences in managerial preferences. ${ }^{30}$ The results indicate that our main findings are generally robust to this model extension.

The third robustness test addresses the fact that in equation (3) each of the bank characteristics interacted with a monetary policy measure are dated $t-1$, even when the policy measure is dated somewhat earlier (e.g., $t-4)$. The dating of characteristics in our baseline regressions is standard in the literature, but it leaves open the possibility that a characteristic value is a function of the earlier policy change with which it is interacted. In order to address this issue we date all characteristics in interaction terms $t-\ell-1$, such that they are pre-determined with respect to the policy variable with which they are interacted (the level characteristics, which

\footnotetext{
${ }^{30}$ The inclusion of fixed effects and autoregressive terms raises the possibility of estimation bias of the form discussed by Nickell (1981). However, the size of this bias declines with the time dimension of the panel, and in our case an average number of time observations per bank of 57 likely means that this bias is minimal. Judson and Owen (1999) find quantitatively small bias for such time dimensions. Interestingly, the autoregressive coefficients change very little across the baseline and fixed effects specifications (results not reported).
} 
enter the regression just once, continue to be dated $t-1$ ). The results from this exercise, performed for both $U M$ and $F F$, are reported in the third column in Table 6. Our findings on the direct effect of policy and bank holding company status are robust. The effects of bank size is consistent only for the UM measure. For the FF the policy interaction with bank size is not only not significant, but significant of opposite sign. For the securities and cash ratio, there is some evidence of a shielding function. Capitalization clearly shields bank level lending growth based on the UM measure.

In the final column in Table 6, we present a version of our baseline results that uses a set of forecasts instead of the actual, realized non-policy macroeconomic controls in $M$ of specification (3). We use the historical data files for the Survey of Professional Forecasters' quarterly time series on nominal gross domestic product, the price index for gross domestic product, and the civilian unemployment rate for the current quarter, the quarter one period ahead and the quarter two periods ahead. ${ }^{31}$

Interestingly, the magnitude of the coefficients on the direct policy response shrinks somewhat, but the difference between the UM and FF measures remains meaningful with the response three times as large in the quarterly model and orders of magnitudes larger in the yearover-year quarterly model. The holding company status and bank size has a shielding effect and is in line with the other estimates. As in the baseline specification, securities act as policy amplifiers in the UM case and mute policy in the case of FF. In contrast to earlier cash shows similar patterns to securities. Capitalization interactions are either insignificant (year-over-year quarterly model) or have an amplifying role.

${ }^{31}$ The data is publically available from the Federal Reserve Bank of Philadelphia at: http://www.philadelphiafed.org/research-and-data/real-time-center/survey-of-professional-forecasters/data-files/ 
Table 6: Robustness Checks

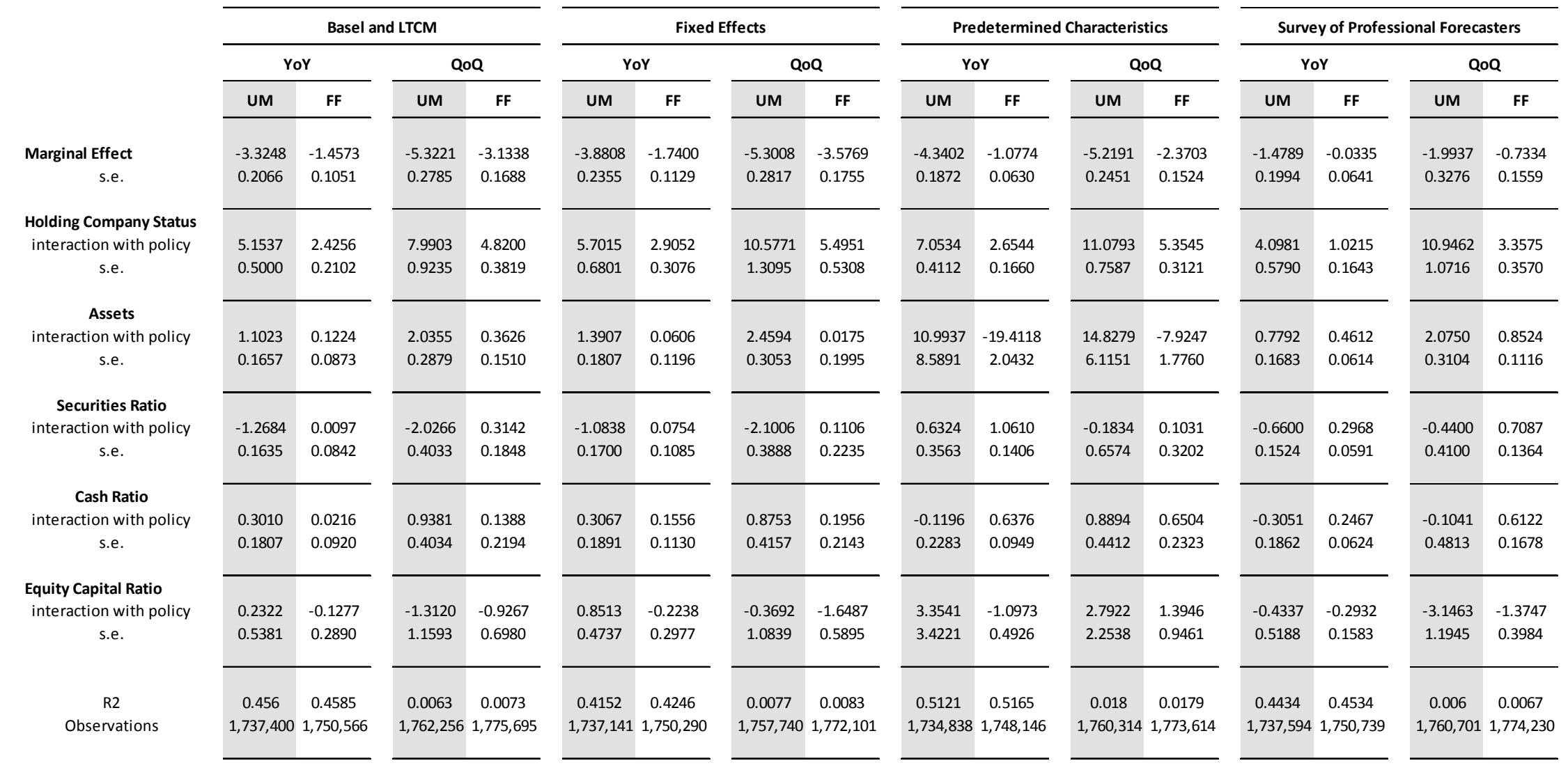

Note: The reported lending responses are the sum of contemporaneous and four lagged responses to a 100 basis points policy tightening. Interaction effects are calculated for a bank one standard deviation above the quarter sample average for a characteristic. Standard errors obtained after clustering at the bank level are reported in parenthesis. ${ }^{* *}$ and ${ }^{*}$ indicate significance at the 1 and 10 percent levels respectively. 


\section{Conclusion}

The credit market turmoil in the wake of the financial crisis and Great Recession has highlighted the critical role played by the banking system in the transmission of monetary policy to the real economy. Recently, policymakers have focused on the way in which banking sector conditions have blunted the stabilizing effects of the large interest rate reductions implemented by the FOMC during the first half of 2008 (Rosengren, 2008). During the last decade, considerable progress has been made in identifying the features of the banking industry that matter for monetary transmission, especially following the creation of the large database on the activities of FDIC-insured banks in the United States in work by Kashyap and Stein (2000). The bulk of this research has used the realized federal funds rate to measure monetary policy. The key point emphasized in our paper is that such a policy measure is endogenous to expected future macroeconomic conditions, which are likely to exert separate effects on both loan demand and loan supply. We have set out examples of such effects and have argued that they may induce bias in both the estimated direct impact of monetary policy on bank lending and in the estimated impact conditional upon bank characteristics. In the empirics, we provided a comparison of the heterogeneity in bank lending responses to an explicitly identified monetary policy measure and the realized interest rate which is more commonly used in the literature.

The results indicate both economically and statistically significant attenuation of estimated lending responses to monetary contractions, accompanied by the shielding of lending associated with bank holding company affiliation. We also found sign reversals in the effects conditional upon some characteristics. Specifically, the share of securities in total assets was shown to amplify policy transmission from exogenous interest rate changes, while restricting the transmission of realized interest rate changes. One explanation for this result is that many types of securities are subject to an adverse valuation effect following exogenous monetary policy contractions, which limits the scope for lending at banks that hold them in large numbers. In contrast, endogenous rises in the federal funds rate may be associated with lending increases (due to the underlying macroeconomic conditions to which policy is endogenous) at banks which choose to invest heavily in securities.

An important research implication from our work is that future studies of the banking system and monetary transmission should consider exogenous policy measures, alongside other measures such as the realized federal funds rate. In particular, the identification of exogenous monetary policy should take into account the forward-looking drivers of monetary policy such as growth and inflation forecasts, because these forward-looking variables are likely to impact lending markets. Interesting avenues for future work include the examination of the impact of exogenous monetary policy upon regional, industrial, and firm-specific lending. It would then be possible to compare these impacts with those from the realized federal funds rate, and to consider their consistency with the banking sector structure relevant to the associated regions, industries, and firms. One possibility is that heterogeneity in the banking sector may account for a larger proportion of the differential effects of monetary policy across these units when an exogenous 
policy measure is employed (see section 4 discussion). Other interesting areas for future work include the application of the methodology used here to study heterogeneity in lending rates, as opposed to lending quantities. In addition, it would be useful to investigate the effects of bank characteristics on responses to policy at a more disaggregated level, such as the relationship to the particular mixture of securities held as bank assets. 


\section{REFERENCES}

Ashcraft, Adam B., 2001, "New Evidence on the Lending Channel," Federal Reserve Bank of New York Staff Report, Vol. 136.

, 2006, "New Evidence on the Lending Channel," Journal of Money, Credit, and Banking, 38, Vol. 3, pp. 751-75.

, 2008, "Are Bank Holding Companies a Source of Strength to their Banking Subsidiaries?" Journal of Money, Credit, and Banking, Vol. 40, No. 2-3, pp. 273-94, March-April.

Bernanke, Ben S. and Alan S. Blinder, 1992, "The Federal Funds Rate and the Channels of Monetary Transmission," American Economic Review, Vol. 82, No. 4, pp. 901-21, September.

Bernanke, Ben S. and Mark L. Gertler, 1989, “Agency Costs, Net Worth, and Business Fluctuations," American Economic Review, Vol. 79, No. 1, pp. 14-31, March.

, 1995, "Inside the Black Box: The Credit Channel of Monetary Policy Transmission. Journal of Economic Perspectives, Vol. 9,No. 4, pp. 27-48, Fall.

Bernanke, Ben S. and Ilian Mihov, 1998, "Measuring Monetary Policy," Quarterly Journal of Economics, Vol. 113, No. 3, pp. 869-902, August.

Board of Governors of the Federal Reserve, 2005, The Federal Reserve System Purposes and Functions, Publications Fulfillment, Board of Governors of the Federal Reserve, Washington, DC, USA, Ninth Edition, June.

Bluedorn, John C. and Christopher Bowdler, 2011, "The Open Economy Consequences of U.S. Monetary Policy," Journal of International Money and Finance, Vol. 30, No. 2, pp. 309-36, March.

Boivin, Jean and Marc Giannoni, 2002, "Assessing Changes in the Monetary Transmission Mechanism: A VAR Approach," Federal Reserve Bank of New York Economic Policy Review, Vol. 8, No. 1, pp. 97-111, May.

Boschen, John F. and Leonard O. Mills, 1991, "The Effects of Countercyclical Monetary Policy on Money and Interest Rates: An Evaluation of Evidence from FOMC Documents," Federal Reserve Bank of Philadelphia Working Paper, (91-20). 
, 1995, "The Relation Between Narrative and Money Market Indicators of Monetary Policy," Economic Inquiry, Vol. 33, No. 1, pp. 24-44, January.

Carlino, Gerald and Robert DeFina, 1998, "The Differential Regional Effects of Monetary Policy," Review of Economics and Statistics, Vol. 80, No. 4, pp. 572-87, November.

Cetorelli, Nicola and Linda S. Goldberg, 2012, "Banking Globalization and Monetary Transmission,” Journal of Finance, Vol. 67, No. 50, pp. 1811-43, September.

Christiano, Lawrence J., Martin Eichenbaum, and Charles L. Evans, 1999, "Chapter 2: Monetary Policy Shocks: What Have We Learned and to What End?" in Handbook of Macroeconomics, Vol. 1A, pp. 65-148, (Elsevier B.V.: Amsterdam, Netherlands).

Faust, Jon, and Jonathan H. Wright, 2008, "Efficient Forecast Tests for Conditional Policy Forecasts," Journal of Econometrics, Vol. 146, No. 2, pp. 293-303, October.

Giordani, Paolo, 2004, “An Alternative Explanation of the Price Puzzle," Journal of Monetary Economics, Vol. 51, No. 6, pp. 1271-96, September.

Jonas, Michael R. and Sharmila K. King, 2008, "Bank Efficiency and the Effectiveness of Monetary Policy," Contemporary Economic Policy, Vol. 26, No. 4, pp. 579-89, October.

Judson, Ruth A., and Ann L. Owen, 1999, "Estimating Dynamic Panel Data Models: A Guide for Macroeconomists," Economics Letters, Vol. 65, No. 1, pp. 9-15, October.

Kashyap, Anil K., and Jeremy C. Stein, 2000, "What do a Million Observations on Banks Say about theTtransmission of Monetary Policy?" American Economic Review, Vol. 90, No. 3, pp. 407-28, June.

Kishan, Ruby P., and Timothy P. Opiela, 2000, "Bank Size, Bank Capital, and the Bank Lending Channel," Journal of Money, Credit, and Banking, Vol. 32, No. 1, pp. 121-41, February.

Loutskina, Elena, 2011, “The Role of Securitization in Bank Liquidity and Funding Management," Journal of Financial Economics, Vol. 100, No. 3, 663-84, June.

Meulendyke, Ann-Marie, 1998, U.S. Monetary Policy and Financial Markets. Federal Reserve Bank of New York.

Morgan, Donald P., 1998, "The Credit Effects of Monetary Policy: Evidence Using Loan Commitments," Journal of Money, Credit, and Banking, Vol. 30, No. 1, pp. 102-18, February. 
Nickell, Stephen, 1981, "Biases in Dynamic Models with Fixed Effects," Econometrica, Vol. 49, No. 6, pp. 1417-26, November.

Orphanides, Athanasios, 2003, "The Quest for Prosperity Without Inflation," Journal of Monetary Economics, Vol. 50, No. 3, pp. 633-63, April.

Pagan, Adrian R., 1984, "Econometric Issues in the Analysis of Regressions with Generated Regressors," International Economic Review, Vol. 25, pp. 221-48.

Peek, Joe, and Eric S. Rosengren, 1998, "Bank Consolidation and Small Business Lending: It's Not Just Bank Size that Matters," Journal of Banking and Finance, Vol. 22, Nos. 6-8, pp. 799-819, August.

Romer, Christina D., and David H. Romer, 2004, "A New Measure of Monetary Shocks: Derivation and Implications," American Economic Review, Vol. 94, No. 4, pp. 1055-84, September. , 2008, "The FOMC Versus the Staff: Where Can Monetary Policymakers Add Value?" NBER Working Paper, Vol. 13751, January.

Rosengren, Eric S., 2008, "Implications of a Credit Crunch," Speech delivered to the Business and Industry Association of New Hampshire and the Greater Manchester Chamber of Commerce on 3 September 2008, accessed 10 July 2009 at http://www.bos.frb.org/news/speeches/rosengren/2008/090308.htm.

Strongin, Steven, 1995, "The Identification of Monetary Policy Disturbances Explaining the Liquidity Puzzle,” Journal of Monetary Economics, Vol. 35, No. 3, pp. 463-97, June.

Welsch, Roy E., and Edwin Kuh, 1977, "Linear Regression Ddiagnostics," NBER Working Paper, No. 173, March.

Wooldridge, Jeffrey M., 2003, "Cluster-sample Methods in Applied Econometrics," American Economic Review, Vol. 93, No. 2, pp. 133-38, May. 